\title{
Autecology and growth of Aleppo pine (Pinus halepensis Mill.): a comprehensive study in France
}

\author{
Michel Vennetier ${ }^{*(1+2)}$, Christian Ripert ${ }^{(1)}$, Cyrille Rathgeber ${ }^{(3)}$ \\ * Corresponding author: michel.vennetier@irstea.fr, tel. +33442669922 FAX:+33442669923 / 9965 \\ (1) Irstea, UR RECOVER / EMR, 3275 route de Cézanne, CS 40061, Aix-en-Provence cedex 5, France \\ (2) ECCOREV, Fédération de recherche, Europôle Méditerranéen de l'Arbois, BP 80, 13545 Aix-en-Provence \\ cedex 4, France \\ (3) UMR LERFoB, AgroParisTech, INRA, 54000, Nancy, France
}

\section{Highlights}

- Aleppo pine growth depends on both climate, soil, parent-rock and topography

- Local water balance weight more than climate for

Aleppo pine growth to date

- Two models were computed to assess a tree height site index in all environments

- A practical tool was developed to be used by forest managers

- This tools can easily be adapted to most of Aleppo pine distribution area

\section{Abstract}

Aleppo pine (Pinus halepensis Mill.) is one of the dominant conifer species in the Mediterranean area. Many studies have investigated the role of climate variables (precipitations, temperature) in its occurrence and growth, but few have taken the effect of local site conditions into account, nor their interaction with climate.

This study aimed at thoroughly assessing forest sites potential for Aleppo pine in France, and designing a practical tool to help forest managers implementing these results. The study is based on a network of 512 plots laid out in the French Mediterranean area, where 2158 trees were measured. A site index was computed using a height growth model calibrated on these plots. Using neural networks and partial least square regression models (PLS), we disentangled the effects of climatic factors and local site conditions in Aleppo pine presence and growth.

Local water balance (assessed through topography, soil, geology and legacies of past human activities) was the main factor driving Aleppo pine productivity in the study area. Climate played a significant role as a whole but more important at the species distribution margins, frost and snow limiting Aleppo pine range northwards and in elevation. Based on these results, a practical tool was designed for two different types of mother rocks to help assessing forest site potential for Aleppo pine.

As the span of climate conditions in south-eastern France includes most of those found in Aleppo pine distribution area, except the driest and hottest ones found in its southernmost locations, this study could easily be used or adapted in most other concerned countries. Because of the ongoing climate change and increasing drought in the Mediterranean area, the balance between local and climate factors may change in time and space. Our results show that without an accurate knowledge of local conditions, the impact of climate change cannot be predicted.

\section{Keywords}

Pinus halepensis; Mediterranean forest; Tree growth; Site index; Climatic change

\section{INTRODUCTION}

Aleppo pine (Pinus halepensis Mill.) is one of the most common tree species in the western half of the Mediterranean basin, where it dominates vegetation cover on 3.5 millions hectares (Le Houérou, 2005a). In France, it is abundant on 250,000 ha along the Mediterranean coast, from see level up to $800 \mathrm{~m}$ of altitude (figure 1). The area dominated by Aleppo pine in France was multiplied by 7 in the last 150 years. Most of this expansion was gained by natural regeneration, encroaching in abandoned fields and grassland, or densifying existing stands after wild fires.

Aleppo pine plays a key role in Mediterranean landscape dynamics. Therefore, its biogeography is well documented (Barbéro et al., 1998; Le Houérou, 2005; Ne'eman et al., 2000).

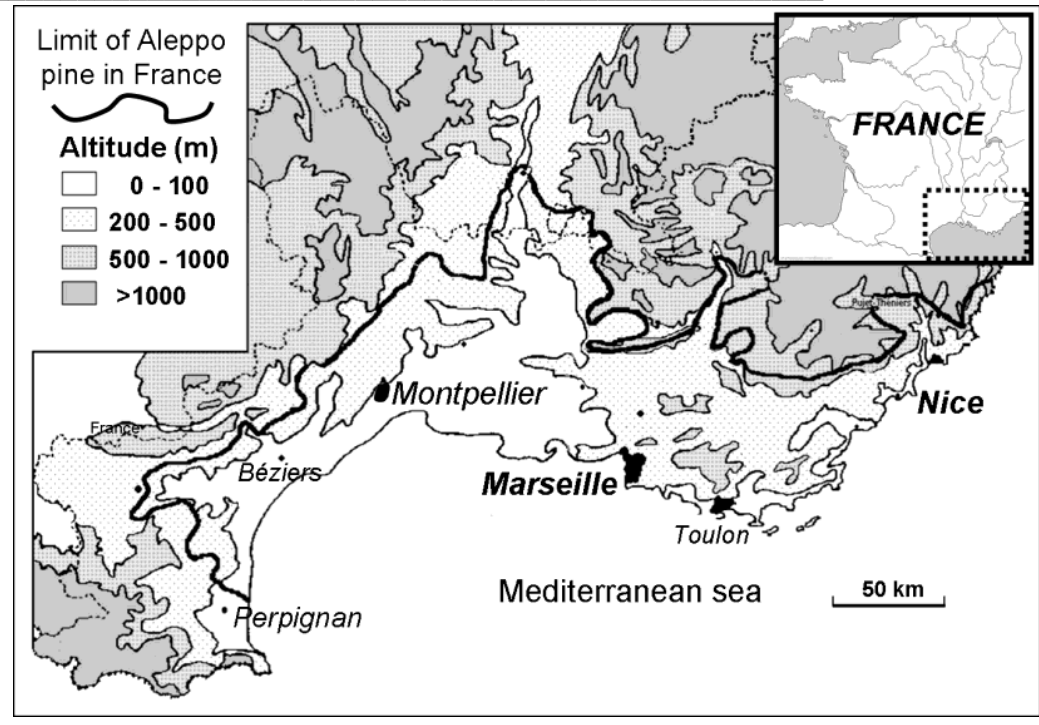

Fig. 1 Limit of Aleppo pine distribution in France. A map of the 523 sampled points of this study is given in appendix 3 . 
It can grow in hot and dry environments, on low fertility soils as well as on rocky calcareous soils (Ne'eman et al., 2000; Quézel et al., 2003). Thanks to its high resistance to heat and drought stresses and to its serotinous cones tolerant to heat (Daskalakou et al., 1996; Verkaik et al., 2006), it is, as a pioneer and undemanding species, one of the main contributors to forest recovery after wildfires (Dubravac et al., 2006; Pausas et al., 2004) as well as on abandoned agricultural land (Achenar et al., 1984; Tatoni et al., 1994a). It even proved to be potentially an invasive species when introduced in new environments (Ganatsas et al., 2010, Zalba et al., 2008). It is also much used for soil protection and rehabilitation in degraded and semi-arid areas (Maestre et al., 2004; Rincon et al., 2006). Relationships between its diameter growth and climate parameters are known through dendroecological studies (De Luis, 2013; Novak et al., 2016; Olivar et al., 2012; Pasho et al., 2012; Sarris et al., 2011; Serre, 1976). Because of its sensitivity to climate, Aleppo pine is an interesting model species for ecophysiologists (Borghetti et al., 1998; David-Schwartz et al., 2016; Prieto et al., 2009) and for plant functioning modellers (Gaucherel et al., 2008; Misson et al., 2004; Rathgeber et al., 2003; Simioni et al., 2016) studying the processes of resistance and adaptation to drought and climate change.

Finally, hundreds of papers give each a part of knowledge on Aleppo pine ecology and adaptation to its environment. But surprisingly, may be because of its plasticity and because it is confined to areas with low wood production potential (Trasobares et al., 2004), comprehensive studies on Aleppo pine sitegrowth relationships and autecology are rare in scientific literature (Bueis et al. 2017, Olarieta 2000). However, such studies are necessary to assess the future of Aleppo pine and to design management strategies in the context of climate change.

An autecological model for a given species aims to predict the effect of all environmental variables and their interactions in the probability of occurrence, the health status and growth of this species (Pianka et al., 2008). A general autecological approach is sometimes used to assess the limits and optimum range for forest trees (Diaz-Maroto et al., 2006). However in forestry, tree development is often associated with biomass or wood production, and autecology to site-yield relationships. "Site" refers to a location, whatever its size, which physical environment is homogeneous. In this context, site index (SI) equate with the overall potential of site environmental parameters to sustain tree growth. Forest productivity is supposed to correlate well with tree height growth (Hägglund, 1981) for a wide range of stand density (Eichhorn, 1904). Thus SI is generally derived from the height of individual trees in unevenaged stands, or from the mean or dominant height of evenaged stands, at a given reference age; it is then defined as "age-height SI" (Skovsgaard et al., 2004). With climate change leading to increasing and more frequent drought stresses, stand density may become a concern: competition for limited water resources between trees, or between dominant trees and the undergrowth, may reduce tree growth and increase mortality risk (Allen et al., 2010), thus question the basis of age-height SI reliability in time. Adaptive management, particularly through more intense or frequent thinnings and clearings, is often recommended to release competition for a sustained height and diameter growth (Gavinet et al. 2015; Giuggiola et al. 2018; Olivar et al., 2014; Sohn et al., 2016).

The goals of this study were: (i) to develop an autecological model, based on a comprehensive study of the relationships between Aleppo pine height growth and occurrence and environmental factors including geography, climate, soil, geology, topography and legacies of past human activities; (ii) to derive from this model a practical tool for forest managers.

\section{Materials and Methods}

\subsection{Study area}

The study area is the French distribution range of Aleppo pine (figure 1), between 42 and $44^{\circ}$ of latitude $(\mathrm{N})$, between 2 and $8^{\circ}$ of longitude $(\mathrm{E})$, and below $1,000 \mathrm{~m}$ of altitude.

The climate is typically Mediterranean. It is characterized by a summer drought lasting two to four months on average combined with very high temperatures, by mild and wet winters, and by rainfall peaks in autumn and spring with a high interannual variability. The annual rainfall and mean temperature range from $450 \mathrm{~mm} / 16^{\circ} \mathrm{C}$, along the western coast and on small islands, to $1100 \mathrm{~mm} / 9.3^{\circ} \mathrm{C}$ in mountain ranges, respectively, with averages around $700 \mathrm{~mm} /$ $13.8^{\circ} \mathrm{C}$. The study area can be split into 3 Mediterranean bioclimates (Rivas-Martínez et al., 2004): the thermomediterranean bioclimate in a narrow strip along the coast, the mesomediterranean bioclimate for plains and low plateaus, and the supramediterranean bioclimate above 500 to $600 \mathrm{~m}$ asl for northern and southern aspects respectively. Aleppo pine cannot be found in France in the oromediterranean bioclimate.

In the study area, Aleppo pine often forms irregular stands issued from natural encroachment on abandoned grasslands and agricultural land. It is sometimes pure, mainly when planted or when issued from natural regeneration of recent forests after wildfire; but it is more frequently mixed with holm oak (Quercus ilex L.) at low elevation and downy oak (Quercus pubescens Willdenow) in the supramediterranean bioclimate. 


\subsection{Sampling design}

Plots were chosen to be representative of the main ecological gradients, as determined by previous studies in the same area (Vennetier et al. 2008, 2010): at least five and a maximum of eight plots were chosen in each of the 96 units of a sampling plan crossing all classes of the following variables:

- Two bioclimate levels (e.g. thermo + meso vs supraMediterranean);

- Four altitude classes: three classes from 0 to $600 \mathrm{~m}$ asl with a span of $200 \mathrm{~m}$ and one class over $600 \mathrm{~m}$ asl; - Four soil types associated with corresponding parent-rock types: (1) alteritic soil on limestone and assimilated carbonated hard rocks; (2) soil on colluvium or alluvium without superficial hard bedrock ; (3) soil on soft carbonated rocks (marl and carbonated clay-stone); (4) non-carbonated soils on other types of parent-rocks, mainly metamorphic as shales, exceptionally sandstones or sand);

- Three classes of solar energy budget, based on Becker index (Becker, 1984) combining orientation and slope (hot, neutral, cool). See appendix 2.c and figure 9 for details.

Within solar energy classes, we also balanced the hot vs very hot and cool vs very cool sites (figure 9). Within each unit of the sampling plan, we tried to balance as far as possible the classes of two other important local factors:

- $\quad$ topography in three classes: (1) concave (i.e. favourable conditions); (2) plane (neutral) (3) convex (i.e. unfavourable);

- $\quad$ soil total depth in three classes $(0-30 ; 30-60$; $>60 \mathrm{~cm})$

Replicates within each sampling design unit were chosen scattered throughout the study area to avoid geographic biases. The sampling plan includes 523 sites, the density of plots being proportional to the surface of Aleppo pine in each county of the study area. The standard plot is a $400 \mathrm{~m}^{2}$ circle. But rectangular plots were used in linear environments as thalwegs and ridges to guaranty homogeneity on site scale.

In order to limit the impact of various disturbances, we chose sites with low levels of recent human activities i.e. no logging, grazing, clearing, trampling or prescribed fires in the last 30 years. No wildfire impacted these plots since the establishment of dominant trees (inferred from the absence of any fire scar on their bole and from the age of broadleaved species found in the plot or in the surroundings). Evidences of ancient human activities (terraces, stone piles or walls, ditches) were noted, as they concern a large proportion of current forests in the study area. But agricultural practices and extensive grazing stopped at least 50 years ago and generally far more, according to forest structure and land registry.

Only healthy dominant trees among the highest in evenaged stands, and the highest of their generation in unevenaged stands, were considered. Five trees per dominant species were chosen in each plot (or all tall trees if less than 5 were present), but up to seven were sampled in unevenaged stands in order to target the different age classes. Tree age was estimated either on cores (three per tree including one as low as possible), or on the stump at soil level after logging in case of stem analysis. 2158 pines (age / height couples) were finally retained. Comparing different sampling methods, Ayari et al., (2011) confirmed that the choice of dominant trees was best suited to examine site fertility for Aleppo pine.

\subsection{Used variables}

The description of variables finally kept in the models is given in table 1 . The patterns of variable transformation described in table 1 are detailed and justified in the first part of the result section: indeed, the shape of site index response to each variable couldn't be decided before the analyses, as it was tested and validated in the modelling process, with several feedback steps. This shape is important to understand the ecology of Aleppo pine, thus it is part of the results.

The study used two types of variables:

- (1) Climatic and geographic variables were generally measured on maps or computed using a GIS: this group includes rainfall and temperature, altitude, the local solar energy budget (Becker, 1984) and topography on landscape scale. For climatic variables, we used 113 meteorological stations of the French National Meteorological Network with complete series of monthly data over 36 years (196196) and 29 additional stations with incomplete series (4 - 30 years) but filling gaps in the National Network (high elevation, slope gradients, shaded slopes). These stations cover the whole study area, and no plot was farer than $25 \mathrm{~km}$ from a meteorological station, $85 \%$ of them being closer than $10 \mathrm{~km}$. Climatic variables were interpolated by simple krieging for rainfall and co-krieging with elevation for temperature, on a grid of $50 \times 50 \mathrm{~m}$ for the whole study area.

- (2) Local variables were directly measured or calculated in the field. They describe topography on local scale, geology, soil and past human impact. A soil profile was studied in each plot, as deeply as possible, up to the unweathered mother rock for relevant geological conditions. It was completed by at least five soil cores, one extracted close to the middle and four close to plot limit at cardinal points. Root density and soil texture were measured in each soil layer. The textural WHC was computed taking the depth of each layer, its proportion of coarse elements, and the WHC of these coarse elements for porous rocks into account. After the first steps of modelling, several variables were split in classes in such a way that the final model can easily be rendered as a practical tool for forest managers. 
Vennetier, M.; Ripert, C., Rathgeber, C. - 2018. Autecology and growth of Aleppo pine (Pinus halepensis Mill.): a comprehensive study in France. Forest Ecology and Management. 413 (2018) $32-47$. https://doi.org/10.1016/j.foreco.2018.01.028

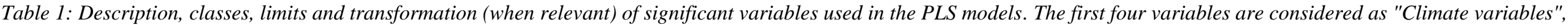
topography on landscape scale as geographical variable, and all other ones are part of "local variables".

The patterns and reasons of variable transformation are detailed in the first part of the result section.

\begin{tabular}{|c|c|c|}
\hline Variable & Limits or classes & Description and transformation when required \\
\hline Altitude & $30-820 \mathrm{~m}$ & Variable transformation: symmetrization ${ }^{(a)}$ on both sides of the optimum $(200 \mathrm{~m})$. \\
\hline $\begin{array}{l}\text { Mean annual } \\
\text { temperature }\end{array}$ & $10.8-16.2^{\circ} \mathrm{C}$ & Variable transformation: a symmetrization on both sides of the optimum $\left(14.5^{\circ} \mathrm{C}\right)$. \\
\hline $\begin{array}{l}\text { Annual rainfall } \\
\text { without summer }\end{array}$ & $400-1150 \mathrm{~mm}$ & $\begin{array}{l}\text { Annual rainfall excluding summer rainfall. Variable transformation: symmetrization on both } \\
\text { sides of the optimum }(850 \mathrm{~mm}) \text {, and constant value }(500) \text { under } 500 \text {. }\end{array}$ \\
\hline Summer rainfall & $58-180 \mathrm{~mm}$ & $\begin{array}{l}\text { Cumulated rainfall of June, July and August. Variable transformation symmetrization on both } \\
\text { sides of the optimum (145 mm). }\end{array}$ \\
\hline $\begin{array}{l}\text { Topography landscape } \\
\text { scale }\end{array}$ & 5 classes, values from 1 to 5 & $\begin{array}{l}\text { Bottom of valleys and thalwegs (5),concave lower slope (4), plain, plateau (3), } \\
\text { regular slope (2), summit, convex ridge or higher slope (1) }\end{array}$ \\
\hline Total soil depth & $0-400 \mathrm{~cm}$ & $\begin{array}{l}\text { Depth up to unweathered mother rock if relevant. Transformation = constant value }(=120) \text { over } \\
120 \mathrm{~cm} .\end{array}$ \\
\hline Colluvium depth & $0->200 \mathrm{~cm}$ & $\begin{array}{l}\text { Transformation }=\text { constant values respectively under } 25 \mathrm{~cm} \text { and over } 100 \mathrm{~cm}, \log \text { transformation } \\
\text { between } 25 \text { and } 100 \mathrm{~cm} .\end{array}$ \\
\hline $\begin{array}{l}\text { Coarse fragments } \\
\text { percentage }\end{array}$ & $0-95 \%$ & $\begin{array}{l}\text { No transformation. On soft carbonated rocks, the percentage of non-weathered parent rock is } \\
\text { considered as coarse fragments percentage. }\end{array}$ \\
\hline $\begin{array}{l}\text { Water holding } \\
\text { capacity index }\end{array}$ & $70-200 \mathrm{~mm} / \mathrm{m}$ & $\begin{array}{l}\text { Assessed from soil texture in classes following the classical texture triangle for texture classes } \\
\text { and table } 4 \text { in Appendix } 2 b \text {. Exponential transformation. Refered thereafter as Textural WHC. }\end{array}$ \\
\hline $\begin{array}{l}\text { local topography } \\
\text { parallel to form lines }\end{array}$ & 3 classes from 1 to 3 & Along form lines: concave (1), flat (0), convex (-1). \\
\hline Dip angle ${ }^{(b)}$ & 5 classes from -2 to +2 & $\begin{array}{l}\text { Sum of two variables = dip angle respectively parallel and perpendicularly to form lines with } 3 \\
\text { classes each: unfavourable }(-1) \text {, intermediate }(0) \text {; favourable (1). See appendix } 2 . a \text { for details }\end{array}$ \\
\hline Slope angle & $0-45^{\circ}$ & Variable (y) transformation: $\mathrm{y}=0$ below $20^{\circ}$, and $\mathrm{y}-20$ over $20^{\circ}$ \\
\hline Rock outcrop \% & $\begin{array}{l}4 \text { classes }=0-3 \\
0 \% ; 1-10 \% ; 10-30 \% ;>30 \%\end{array}$ & No transformation \\
\hline $\begin{array}{l}\text { Coarse fragments } \\
\text { cover at soil surface }\end{array}$ & $0-100 \%$ & $\begin{array}{l}\text { Free rock fragments (pebbles, stones, blocks, excluding alterite outcrops) at soil surface under or } \\
\text { over the litter. No transformation }\end{array}$ \\
\hline $\begin{array}{l}\text { Bedrock vertical } \\
\text { fissuration }\end{array}$ & $\begin{array}{l}5 \text { classes: number of large } \\
\text { cracks/m: NA, } 0 ; 1-2 ; 3-4 ; \geq 5\end{array}$ & $\begin{array}{l}\text { Only relevant on hard rocks. Soft carbonated rocks are noted without cracks (class 1). Set to NA } \\
\text { for statistical analyses (non applicable) when unknown due to a deep soil. }\end{array}$ \\
\hline Active lime & 4 classes: $0-3$ & $\begin{array}{l}\text { Field test of fine earth reaction to } \mathrm{HCl} \text { (diluted at } 10 \% \text { ) after sifting at grain size } \leq 0.5 \mathrm{~mm} \\
0=\text { no reaction to } \mathrm{HCl}, 1=\text { week reaction, few bubbles; } 2=\text { significant and audible reaction but } \\
\text { moderate or partial, } 3=\text { strong audible reaction on all the sample }\end{array}$ \\
\hline Past land uses * & 4 classes: $0-3$ & $\begin{array}{l}0=\text { no remainder or signs of past agriculture; } 1=\text { light: signs of stone removal (stone piles, } \\
\text { walls); } 2 \text { = strong: sign of cultures (ridges, ditches); } 3=\text { topographic transformation (terrasses) }\end{array}$ \\
\hline
\end{tabular}

(a) Symmetrization: for an optimum of $x$, variable $y$ transformed in $y_{s y m}=|x-y|$ 
Vennetier, M.; Ripert, C., Rathgeber, C. - 2018. Autecology and growth of Aleppo pine (Pinus halepensis Mill.): a comprehensive study in France. Forest Ecology and Management. 413 (2018) $32-47$. https://doi.org/10.1016/j.foreco.2018.01.028

* quantifies the level of anthropization of the environment, i.e. the intensity and percentage of topographic and pedological transformations (Tatoni et al., 1994a, b). Classes are sorted according to the impact of these transformations on local water budget (see discussion for details). 


\subsection{Height growth model and site index}

Developing a model based on an age-height SI supposes that a height growth model pre-exists. Vennetier et al. (2010) made a synthesis of all previous works conducted in France (e.g. Rathgeber et al., 2004), and calibrated a new model adapted to any type of stand for Aleppo pine in France, which was used in this study. There was no significant discrepancy between this last model and the older ones, nor with sub-regional models which were tested, proving that Aleppo pine height growth patterns were rather homogeneous in France despite strong climate variability.

Our height growth model (appendix 1) uses ChapmanRichards equations (Richards, 1959). After calibration with our dataset, this model gave the growth curves of figure 2 . All details about the height growth modelling are given in appendix 1 .

Fig. 2 Aleppo pine height growth model and limits of fertility classes in France. Within the span 40 - 110 years, average prediction error on tree SI compared to the real value from stem analysis is always less than $10 \%$

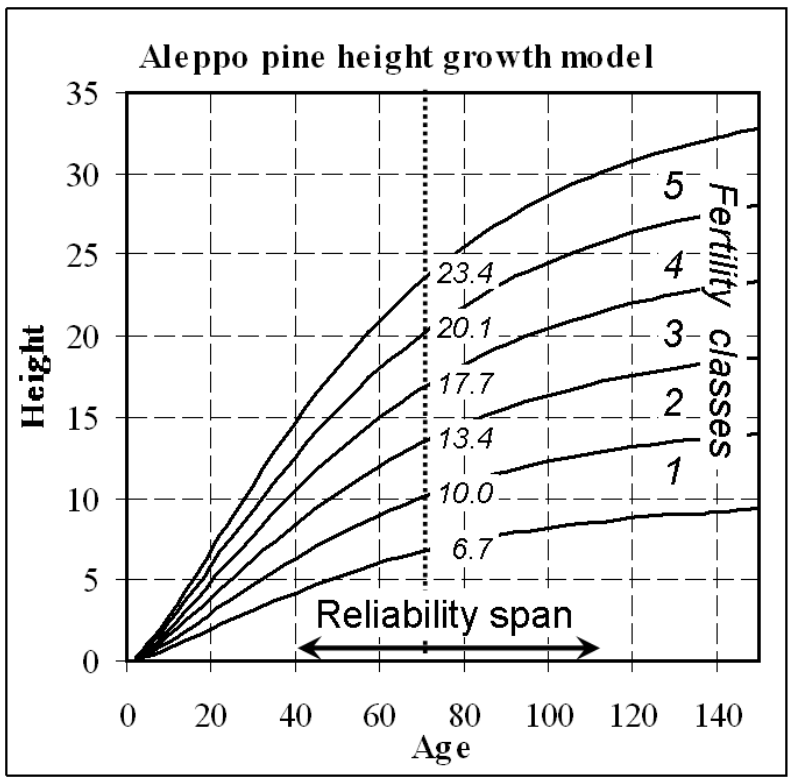

2.5 Site index modelling, statistical analyses and practical tool for forest managers

\subsubsection{Modelling and statistical steps}

We used PLS regression for site index modelling. This method was designed to handle many correlated variables with relatively few observations (Cramer et al., 1988) and it is optimal for linear relationships. After a first round of raw variables selection (initially 50 environmental variables were available), we used neural networks as proposed by Guiot (1991) to obtain the response pattern of site index to each remaining variable (figure 3) and transformed these variables when necessary to linearize the response (table 1). An ascending and descending stepwise PLS regression was used for the final selection of variables. Considering previous studies using most of the same plots, and the first results of this one, we used this process to compute the model with all plots or for four groups of plots (two types of parent rocks and, on one of these types, two types of soils (see table 2 and figures 4 and 5). Selected models were transformed in a tool easy to use in forest management (figure 6): variables were first split in classes which can be discriminated in the field and, when relevant, classes limits were chosen according to SI response pattern; then each class was given a sign related to the response of SI to this variable and a value related to the relative weight of the variable in the model.

\subsubsection{Detailed statistical processes}

In a first step, we chose the number of significant components for a PLS regression with a 10,000-replications permutation test on observations. Components whose percentage of explained variance was not passed by more than $5 \%$ of the permutations were kept.

In a second step, variables were assessed through a 1,000resampling cross-validation test. We rejected variables when the confidence interval $(95 \%)$ of their partial correlation coefficient included zero.

Neural network were optimized with a 200-replication bootstrap, each replication including 3000 calibration steps. After the optimization of a neural network, the response of each variable (figure 3) was plotted on its whole variation interval, the other variables being maintained at their mean value if they were not correlated with the tested one, or maintained successively at their first, second and third thirds for those which were correlated. In the last case, the three responses were combined in a sliding weighted mean to obtain the global response. We only transformed a variable according to a non-linear relationship proposed by neural networks when this relation was stable throughout these many tests, while it enhanced whether the total explained variance of the model, or variable partial correlation coefficient in the model.

We used R software (R Development Core Team, 2010) for PLS regression and PPPhalos software (Guiot, 1991) for neural networks.

The distribution of plots is not homogeneous in the fertility classes. It follows a Gaussian curve with few plots in the highest and lowest classes which are rare. Without weighting, the intermediate classes are over-represented and the models hardly predict the better and worse SI with residuals often over $4 \mathrm{~m}$. We corrected this unbalanced distribution weighting each plot by the square of the distance between its site index and the mean site index of the whole sample (equation 1). With such a correction, the mean residual of both extreme fertility classes were reduced by $20 \%$, while they remained nearly unchanged for intermediate classes $(+5 \%)$. The mean standard deviation of for all errors was also reduced by more than $10 \%$.

Equation 1 Plot weight related to its site index relative value:

$$
\mathrm{Pi}=1+(\mathrm{H} 70-\mathrm{Hi} 70)^{2} / 10.5
$$

$\mathrm{Pi}=$ weight for plot $\mathrm{i}, \mathrm{H} 70=$ mean site index for all plots, $\mathrm{Hi} 70=$ site index of plot $\mathrm{i}$,

$10.5=$ half of the total span of site index variation 


\section{RESULTS}

\subsection{Age classes of sampled trees}

The age of sampled trees ranged from 35 to 180 years, with a mean of 70 . Over $600 \mathrm{~m}$ asl, we never found healthy Aleppo pines over 100 years old nor standing individuals over 120 years. At such elevation, most of old sampled trees were suffering from severe fungus attacks on the bole and heartwood rotting, preventing us to reach the pith with the cores, and playing a prominent and visible role in their early death through windthrows. At the northern limit of Aleppo pine distribution, and over $800 \mathrm{~m}$ in elevation, nearly all Aleppo pines were shaped by the after-effects of repeated breaks by snow or freezing fog on the bole and in the crown, making it difficult to accurately assess past height growth without a thorough stem analysis. No tree older than 100 years was found in these conditions. This demonstrated a strong physical limitation of Aleppo pine distribution by cold climates.

\subsection{Thresholds, optima and limits of site conditions}

The relationships between SI and the main environmental variables are complex (Figure 3). SI was higher below an elevation of $300 \mathrm{~m}$ with a slight fall under $100 \mathrm{~m}$ and between 13.8 and $15.3^{\circ} \mathrm{C}$, with optima around $200 \mathrm{~m}$ and $14.5^{\circ} \mathrm{C}$. The ideal rainfall ranged, for summer rainfall and annual mean minus summer rainfall, from 120 to $150 \mathrm{~mm}$ and from 750 to $950 \mathrm{~mm}$, respectively. These limits corresponded, for sampled plots, to an annual rainfall between 850 and $1100 \mathrm{~mm}$.

Two thresholds were observed for colluvium depth: up to $25 \mathrm{~cm}$, few differences were found with a pure alterite. Over $25 \mathrm{~cm}$, SI increased sharply up to $70 \mathrm{~cm}$ and remained stable over $100 \mathrm{~cm}$. These two limits cohered with the $110 \mathrm{~cm}$ threshold observed for soil total depth, over which SI stagnated. Site index responded linearly to the percentage of coarse fragments, with only a slight inflexion below $20 \%$. The water holding capacity index (WHC) responded on both ends of its distribution, but finally, an exponential transformation better improved its contribution to the model. Slope had no impact on SI up to 20 degrees and a linear negative effect over this limit.

\subsection{Choice and optimization of several PLS models}

Variables were first transformed according to the shape of SI response in neural networks analysis. When all plots were included in the model, the mean absolute prediction error was high $(1.7 \mathrm{~m})$. Twelve residuals were over four meters and 38 between 4 and $3.3 \mathrm{~m}$, over the span of one fertility class. In fact, most of these outliers laid on soft carbonated rocks (SCR) as marls and carbonated clay-rock, often in degraded sites referred to as "badlands". Their SI was generally overestimated by the model, with a few exceptions showing an underestimation. These substrates induce specific chemical and physical constraints (Antoine et al., 1995; Esteves et al., 2005) discussed in the next section. Thus, two models were computed, separating the 40 plots on SCR and other plots (figure 4), with a better explained variance and lower residuals (table 2). In the model with all plots together, soils on alterite had a significantly lower mean SI than soils on colluvium in the same classes of soil depth. Distinguishing these two types of soils was part of the sampling design. According to the response of SI to colluvium depth, showing a threshold of $25 \mathrm{~cm}$ for the colluvial superficial layer, we computed a PLS model for each group of plots: with (colluvium) and without (alterite) more than $25 \mathrm{~cm}$ of colluvium (figure 5). None of these two models was better than the model with all plots excluding SCR for SI prediction (table 2), and although a little bit worse in terms of mean absolute prediction error, they had similar standard deviations for prediction errors and residuals. Thus we considered these two models as an alternative to the model with all plots without SRC. Their differences helped disentangling the respective roles of some variables (soil depth, colluvium depth, past land uses, water holding capacity, rock fissuration, coarse fragment) in Aleppo pine growth, through site water balance and Aleppo pine root system adaptation to different constraints. They highlight important aspects of Aleppo pine ecology, which are further discussed
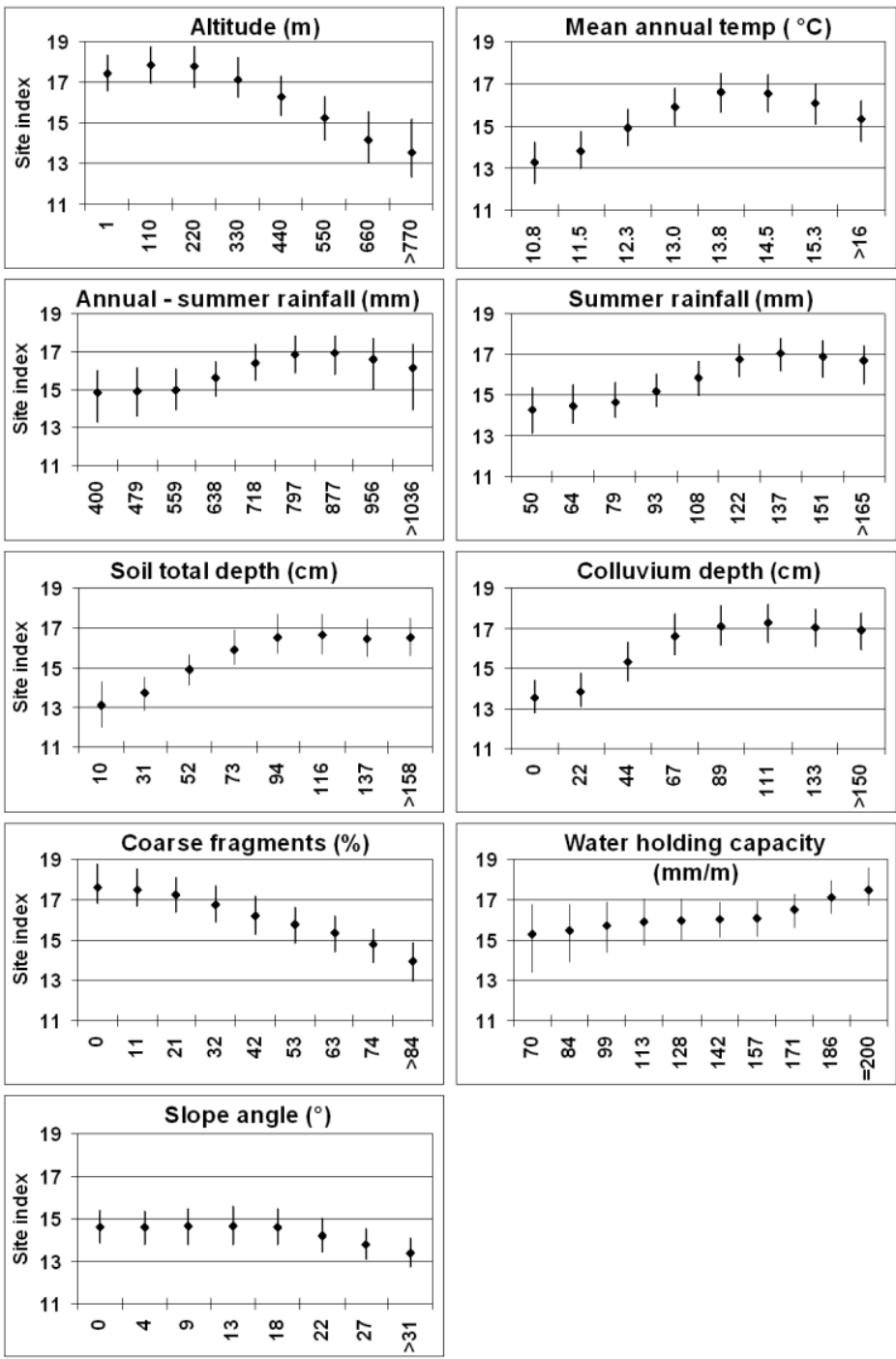

Fig.3 Response of Site Index to the main environmental variables requiring a transformation, according to neural networks analysis. Vertical bars give the confidence interval $\left(5^{\text {th }}-95^{\text {th }}\right.$ percentiles $)$. Other variables showed a linear response 
Table 2 Comparison of the five PLS models, including (1) all the plots (2) two groups of plots: with and without soft carbonated rocks (SCR) and (3) two groups of plots: with (colluvium) and without (alterite) a significant colluvium (>25 cm depth). NS means non-significant. This table gives the mean for absolute values of the prediction error.

\begin{tabular}{|c|l|c|c|c|c|c|c|c|}
\cline { 2 - 9 } \multicolumn{2}{c|}{} & $\begin{array}{c}\text { Nb of PLS } \\
\text { components }\end{array}$ & $\begin{array}{c}\% \text { explained } \\
\text { variance }\end{array}$ & $\begin{array}{c}\text { Comp 1 } \\
\%\end{array}$ & $\begin{array}{c}\text { Comp 2 } \\
\%\end{array}$ & $\begin{array}{c}\text { Mean abs. } \\
\text { prediction error }\end{array}$ & $\begin{array}{c}\text { SD. } \\
\text { prediction } \\
\text { error }\end{array}$ & $\begin{array}{c}\text { SD of } \\
\text { residuals }\end{array}$ \\
\hline 1 & All plots & 2 & 51 & 45 & 6 & 1.7 & 1.7 & 3.0 \\
\hline \multirow{2}{*}{2} & Without SCR & 2 & 55 & 49 & 6 & 1.3 & 1.1 & 1.9 \\
\cline { 2 - 10 } & SCR & 1 & 56 & 56 & NS & 1.4 & 1.1 & 1.9 \\
\hline \multirow{2}{*}{3} & Colluvium & 2 & 48 & 41 & 7 & 1.6 & 1.1 & 1.9 \\
\cline { 2 - 10 }$y$
\end{tabular}

0.3

Annual Rainfall without summer Total soil depth Topography Lanscape Scale Topography local Scale Imbricated plates Rock Fissuration Water Holding Capacity Altitude Mean Annual Température Colluvium Depth

Past landuses Summer rainfall Dip angle

Rock Outcrop Coarse Frag Surf $\%$ Coarse Fragments \% Active lime Slope Angle

0.3

Total soil depth Rock Fissuration Coarse Frag Surf Annual Rainfall without summer Topography Lanscape Scale Mean Annual Température Imbricated plates

Summer rainfall Topography local Scale Altitude

Rock Outcrop Water Holding Capacity Dip angle Active lime Coarse Fragments \% Past landuses Colluvium Depth
0.2

0.1

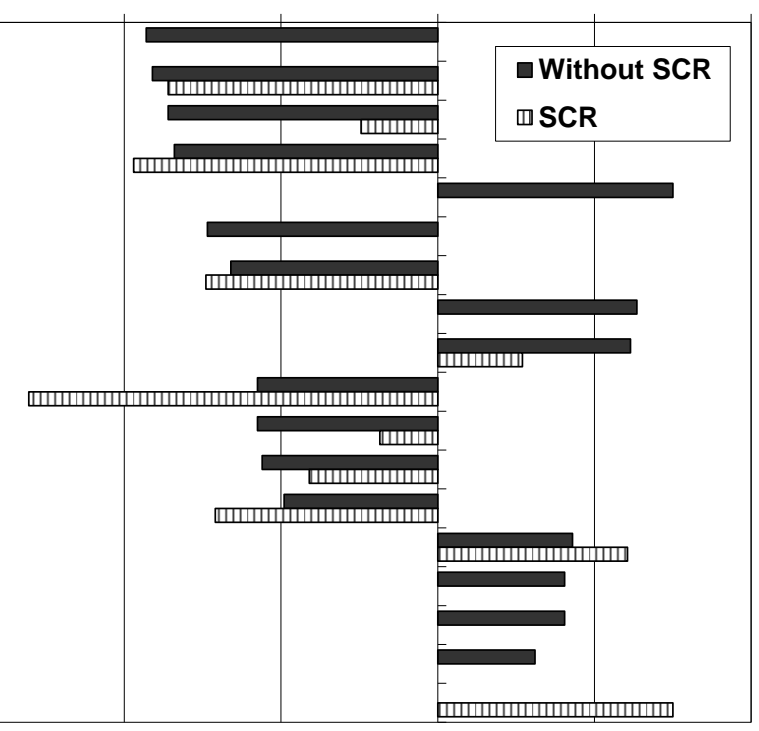

0.2

0.1

0

$-0.1$

$-0.2$
QAlterite

D Colluvium $>25 \mathrm{~cm}$

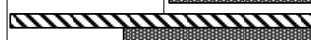

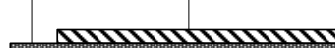
कापापायापाया

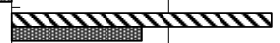

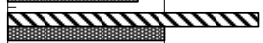

समाप

101001010

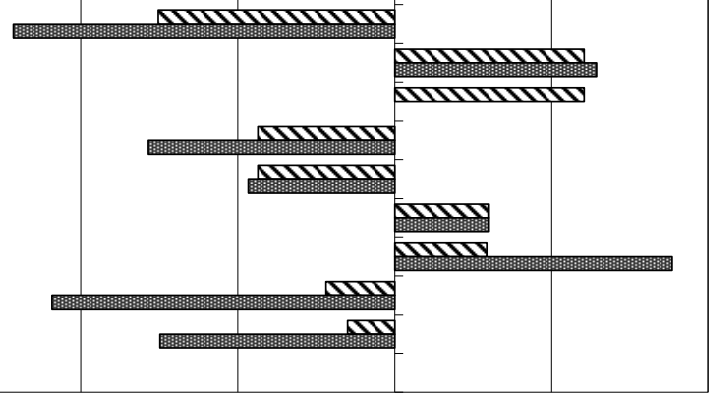

Fig.4 Partial correlation coefficients of the PLS models for (i) all parent-rocks excluding soft carbonated rocks (SCR) and (ii) for SCR only. All displayed variables are significant $(p<0.05)$ in the PLS regression. Variables are sorted by decreasing weight in the model without SRCs.
Fig.5 Partial correlation coefficients of the PLS models without SCR for (i) alterites and (ii) soils with more than $25 \mathrm{~cm}$ of colluvium. All displayed variables are significant $(p<0.05)$ in the $P L S$ regression for at least one of the groups. Variables are sorted by decreasing weight in the model for alterite. 


\subsection{Comparison between models \& additional results}

Aleppo pine productivity was significantly responsive to many factors: topography on local and landscape scale, several soil parameters (structure, depth, rockiness and coarse fragment content, active lime, water holding capacity), characteristics of superficial bedrocks (dip and fissuring, outcrops), climate (temperature and rainfall) and past land uses.

Local factors dominated in all models compared to climate and altitude. When summed together, they represented $\sim 75 \%$ of SI explained variance on non-SCR rocks, and $90 \%$ on SCR.

On SCR, annual rainfall and altitude were not significant, and climate as a whole had a very light weight in the model (represented by mean annual temperature and summer rainfall with very small coefficients). Topography and past land uses had a smaller weight on SCR than on other substrates. Active lime was significant for all groups of plots except, logically, SCR where its percentage is always very high. Except dip, bedrock characteristics used in this study were irrelevant on SCR.

Geological factors as well as soil total depth and surface stone cover were more important on alterite than on colluvium. Conversely, local topography, soil water holding capacity, past land uses and the percentage of coarse elements were more important on colluvium.

Mean SI was higher in the eastern part of the study area than in its western part. Soil texture, driving water holding capacity, also had a significant influence on rooting density; a balanced texture mixing a significant proportion of the three main components (sand, silt and clay) increased by $60 \%$ root density in the soil profile compared to unbalanced textures limited to one or two of these components (11.5 vs 7 roots $\left./ \mathrm{dm}^{2}, \mathrm{P}<0.01\right)$.

\subsection{Practical tools for site index assessment}

The practical tool derived from the PLS models is shown in figure 6. As splitting soil in alterite and colluvium did not improve the accuracy of predictions nor reduced the standard deviation of errors, a single practical tool was developed for all rocks excluding SCR. Models for alterite and colluvium may be useful for research purpose, for in depth field surveys and for further investigations in sites badly predicted by the proposed practical tool.

\section{DISCUSSION}

\subsection{Reliability of site index (SI)}

The tenets of height/age SI concept can be questioned:

- $\quad$ (1) On one hand, thinnings may interfere with site quality in stand growth (Olivar et al, 2014; Skovsgaard et al., 2008). But none of our plots were thinned in the last 30 years, and most of them remained unmanaged since at least the 50 's. As $80 \%$ of studied stands can be considered as unevenaged and irregular, with rather low densities and low to moderate competition between dominant trees, computing individual tree SI was compulsory. Young Aleppo pines in these plots occupy former gaps resulting from natural hazards as storms, snow, deep frosts and insect outbreaks. But we did not choose plots with recent accidents, nor young trees strongly competing with older ones. Finally, tree density at individual level can be considered as rather stable in our plots and probably have little influence on observed growth patterns.

- (2) On the other hand, assessing forest growth from age-height SI supposes that, for a given site, height growth pattern is stable in time. A static definition of "site" ignores environmental dynamics that may improve or hamper tree growth, such as global and climate change (Cannel, 1998), land-use change and derived soil evolution (Glatzel, 1998). Indeed, convergent results in France (Becker et al., 1994; Rolland et al., 1998), in Europe (Spiecker et al., 1996) and throughout the world (Backer et al., 2004; Cook et al., 1991; D'Arrigo et al., 1996; Szeicz, 1997) show that tree height growth varied in the 20th century, and particularly since the 60's. Most of the time a significant acceleration was reported, and Aleppo pine clearly followed this general trend (Vennetier et al., 1998). We got around this problem with the correction of site index according to tree age (equation 3 ), so that our model should not be biased by the global change-related height growth evolution.

Flora composition, as an integrated indicator of site conditions, was sometimes used independently or combined with abiotic variables to assess site index (Berges et al., 2006). In the Mediterranean region, flora composition is generally constrained by millenniums of severe disturbances (Blondel and Aronson, 1999) and, even dozens of years after the release of anthropic pressure, may still be in fast evolution (Tatoni et al., 1994b) and not representative of site environment. Moreover, trees like Aleppo pine can reach deep water and nutrients resources inside bedrocks (Sarris et al., 2013), out of reach of most other plants. This is demonstrated by the importance of geological variables for Aleppo pine growth, and particularly parent rock fissuration and dip. Such variables did not appear in the bioclimatic model calibrated on the whole flora in the same study area, and for a large proportion on the same plots (Vennetier et al., 2008). Thus we used only abiotic variables to model the site index, to allow the model to be used accurately in any circumstance and place whatever the degradation level or the evolution stage of present or future vegetation. 
Vennetier, M.; Ripert, C., Rathgeber, C. - 2018. Autecology and growth of Aleppo pine (Pinus halepensis Mill.): a comprehensive study in France. Forest Ecology and Management. 413 (2018) 32-47. https://doi.org/10.1016/j.foreco.2018.01.028

Fig.6: Tables and graphs to assess Aleppo pine Site Index with simplified field data. The value "Total all variables" from each table must be used in the corresponding graph of fig 6.3 to get the predicted site index (SI).

Fig. 6.1 Tool for all parent rocks except soft carbonated rocks (for SRC, see fig 6.2).

\begin{tabular}{|c|c|c|c|c|c|c|c|c|c|c|c|c|c|c|c|c|c|c|c|c|c|}
\hline \multirow{2}{*}{$\begin{array}{l}\text { Variable } \\
\text { Classes }\end{array}$} & \multicolumn{6}{|c|}{ Summer rainfall $(\mathrm{mm})^{(1)}$} & \multicolumn{6}{|c|}{ Mean annual rainfall $(\mathrm{mm})^{(1)}$} & \multicolumn{9}{|c|}{ Mean annual temperture $\left({ }^{\circ} \mathrm{C}\right){ }^{(1)}$} \\
\hline & $<70$ & $70-85$ & 85-95 & $95-115$ & $115-160$ & $>160$ & $<600$ & $\begin{array}{c}600- \\
700\end{array}$ & $\begin{array}{c}700- \\
780\end{array}$ & $\begin{array}{c}780- \\
850\end{array}$ & \begin{tabular}{|l|}
$850-$ \\
1050
\end{tabular} & $>1050$ & $<10.9$ & \begin{tabular}{c|}
$10.9-$ \\
11.6
\end{tabular} & \begin{tabular}{c|}
$11.6-$ \\
12.1
\end{tabular} & \begin{tabular}{c|}
$12.1-$ \\
12.6
\end{tabular} & \begin{tabular}{c|}
$12.6-$ \\
13.2
\end{tabular} & $\begin{array}{c}13.2- \\
14.4\end{array}$ & \begin{tabular}{c|}
$14.4-$ \\
15
\end{tabular} & \begin{tabular}{|c|}
$15-$ \\
15.5
\end{tabular} & $>15.5$ \\
\hline Value & -0.5 & -0.3 & 0 & 0.3 & 0.5 & 0 & -1.8 & -0.6 & 0 & 0.9 & 1.8 & 0 & -0.93 & -0.65 & -0.33 & 0 & 0.5 & 0.9 & 0.465 & 0 & -0 . \\
\hline Note & & & & & & & & & & & & & & & & & & & & & \\
\hline
\end{tabular}

\begin{tabular}{|c|c|c|c|c|c|c|c|c|c|c|}
\hline \multirow{2}{*}{$\begin{array}{l}\text { Variable } \\
\text { Classes }\end{array}$} & \multicolumn{10}{|c|}{ Landform } \\
\hline & $\begin{array}{l}\text { Valley } \\
\text { thalweg }\end{array}$ & \begin{tabular}{|} 
Concave \\
lower slope
\end{tabular} & \begin{tabular}{|c} 
plain \\
plateau
\end{tabular} & $\begin{array}{l}\text { regular } \\
\text { slope }\end{array}$ & $\begin{array}{l}\text { Convex } \\
\text { ridge or } \\
\text { higher } \\
\text { slope }\end{array}$ & concave & plane & $\begin{array}{l}\text { con- } \\
\text { vex }\end{array}$ & yes & no \\
\hline Value & 2.2 & 0.7 & 0 & -0.3 & $\begin{array}{l}-1.5 \\
\end{array}$ & 2.0 & 0 & -2.0 & 4.0 & 0 \\
\hline Note & & & & & & & & & & \\
\hline
\end{tabular}

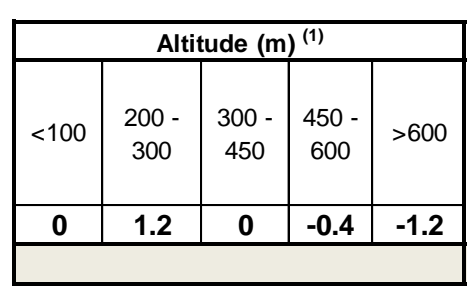

Total landform

Soil surface

\begin{tabular}{|c|c|c|c|c|c|c|c|c|c|c|c|}
\hline Variable & \multicolumn{3}{|c|}{ Coarse fragments } & \multicolumn{4}{|c|}{ Rock outcrops } & \multicolumn{4}{|c|}{ Colluvium depth (cm) } \\
\hline Classes & $<10 \%$ & $10-30 \%$ & $>30 \%$ & 0 & $1-10 \%$ & $10-30 \%$ & $>30 \%$ & $<25$ & $25-40$ & $40-70$ & $>70$ \\
\hline Value & 0.5 & 0 & -0.5 & 1.0 & 0.4 & -0.4 & -1.0 & 0.0 & 0.2 & 0.4 & 0.7 \\
\hline Note & & & & & & & & & & & \\
\hline
\end{tabular}

\section{Bedrock}

\begin{tabular}{|c|c|c|c|c|c|c|c|c|c|c|}
\hline Variable & \multicolumn{9}{|c|}{ Rock layers dip (2) $^{2}$} & \multicolumn{3}{|c|}{ Rock fracturation } & \multicolumn{2}{|c|}{ Plates ${ }^{(3)}$} \\
\hline Classes & -2 & -1 & 0 & 1 & 2 & low & mean & high & yes & no \\
\hline Value & $-\mathbf{0 . 6}$ & $-\mathbf{0 . 3}$ & $\mathbf{0}$ & $\mathbf{0 . 3}$ & $\mathbf{0 . 6}$ & $-\mathbf{0 . 6}$ & $\mathbf{0}$ & $\mathbf{0 . 6}$ & $\mathbf{- 1 . 8}$ & $\mathbf{0}$ \\
\hline Note & \multicolumn{10}{|c|}{} \\
\hline
\end{tabular}

Soil

\begin{tabular}{|c|c|c|c|c|c|c|c|c|c|c|c|c|c|c|c|c|c|c|c|}
\hline Variable & \multicolumn{5}{|c|}{ Water holding capacity $(\mathrm{mm} / \mathrm{m})^{(4)}$} & \multicolumn{7}{|c|}{ Soil total depth $(\mathrm{cm})$} & \multicolumn{7}{|c|}{$\%$ coarse elements } \\
\hline Classes & $<100$ & $100-140$ & $\begin{array}{c}140- \\
180\end{array}$ & $\begin{array}{c}180- \\
196\end{array}$ & $>196$ & $<35$ & $35-60$ & $60-75$ & $75-90$ & $\begin{array}{l}90- \\
110\end{array}$ & \begin{tabular}{|c|}
$110-$ \\
180
\end{tabular} & $>180$ & 0 & $1-20$ & $20-40$ & $40-60$ & $60-80$ & $80-95$ & $>95$ \\
\hline Value & $\begin{array}{l}-1.3 \\
\end{array}$ & -0.6 & 0 & 0.8 & 1.3 & -2.6 & -0.9 & -0.3 & 0 & 0.6 & \begin{tabular}{|l|}
1.2 \\
\end{tabular} & 1.7 & 0 & 1.4 & 0.5 & 0 & -0.5 & -1.0 & -1.4 \\
\hline Note & & & & & & & & & & & & & & & & & & & \\
\hline
\end{tabular}

(1) to be adapted to local climate gradients and constraints in other regions

(2) see in annex 2.a how to assess dip classes

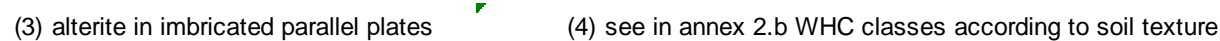

Total all variables

Total surface

All rocks except SCR

Total rock

Total soi 
Vennetier, M.; Ripert, C., Rathgeber, C. - 2018. Autecology and growth of Aleppo pine (Pinus halepensis Mill.): a comprehensive study in France. Forest Ecology and Management. 413 (2018) 32-47. https://doi.org/10.1016/i.foreco.2018.01.028

Fig 6.2 Tool for soft carbonated rocks (SRC): marls, carbonated clay-rock and similar rocks

\section{Climate}

\begin{tabular}{|c|c|c|c|c|c|c|c|c|c|c|c|c|c|c|c|}
\hline Variable & \multicolumn{6}{|c|}{ Mean annual rainfall $(\mathrm{mm})^{(1)}$} & \multicolumn{6}{|c|}{ Summer rainfall $(\mathrm{mm})^{(1)}$} & \multicolumn{3}{|c|}{ Mean annual temp ${ }^{(1)}$} \\
\hline Classes & $<600$ & $\begin{array}{c}600- \\
700\end{array}$ & $\begin{array}{c}700- \\
780\end{array}$ & $\begin{array}{c}780- \\
850\end{array}$ & $\begin{array}{l}850- \\
1050\end{array}$ & $>1050$ & $<70$ & $70-85$ & $85-95$ & $\begin{array}{l}95- \\
115\end{array}$ & $\begin{array}{l}115- \\
160\end{array}$ & $>160$ & $<11.6$ & $\begin{array}{c}11.6- \\
15\end{array}$ & $>15$ \\
\hline Value & -1.3 & -0.5 & 0 & 0.7 & 1.3 & 0 & -0.5 & -0.3 & 0.0 & 0.3 & 0.6 & 0 & -0.9 & 0 & -0.6 \\
\hline Note & & & & & & & & & & & & & & & \\
\hline
\end{tabular}

Landform

\begin{tabular}{|c|c|c|c|c|c|c|c|c|c|c|c|c|c|}
\hline Variable & \multicolumn{5}{|c|}{ General topography } & \multicolumn{3}{|c|}{ Transversal topogr } & \multicolumn{2}{|c|}{ Terrasses } & \multicolumn{3}{|c|}{ Slope angle $\left({ }^{\circ}\right)$} \\
\hline Classes & $\begin{array}{c}\text { Valley } \\
\text { thalweg }\end{array}$ & $\begin{array}{c}\text { Concave } \\
\text { lower } \\
\text { slope }\end{array}$ & $\begin{array}{c}\text { plain } \\
\text { plateau }\end{array}$ & $\begin{array}{l}\text { regular } \\
\text { slope }\end{array}$ & $\begin{array}{c}\text { Convex } \\
\text { ridge or } \\
\text { higher } \\
\text { slope }\end{array}$ & $\begin{array}{l}\text { con- } \\
\text { cave }\end{array}$ & plane & convex & yes & no & $<20$ & $20-30$ & $>30$ \\
\hline Value & 1.8 & 0.6 & 0 & -0.2 & -1.2 & 2.2 & 0 & -2.2 & 2 & 0 & 0 & -0.5 & -1.5 \\
\hline Note & & & & & & & & & & & & & \\
\hline
\end{tabular}

\begin{tabular}{|c|c|c|c|c|}
\hline \multicolumn{5}{|c|}{ Altitude (m) } \\
\hline \multirow{2}{*}{$<100$} & $200-$ & $300-$ & $450-$ & \\
& 300 & 450 & 600 & $>600$ \\
\hline 0 & 1.2 & 0 & -0.4 & -1.2 \\
\hline
\end{tabular}

Total landform

Rock

\begin{tabular}{|c|c|c|c|c|c|c|c|c|c|}
\hline Variable & \multicolumn{3}{|c|}{ Parent rock outcrop } & \multicolumn{5}{c|}{ Local rock layer dip $\left({ }^{*} 2\right)$} \\
\hline Classes & 0 & $1-10 \%$ & $10-30 \%$ & $>30 \%$ & -2 & -1 & 0 & 1 & 2 \\
\hline Value & $\mathbf{0 . 5}$ & $\mathbf{0 . 2}$ & $-\mathbf{0 . 2}$ & $\mathbf{- 0 . 5}$ & $-\mathbf{1 . 9}$ & $\mathbf{- 9 . 5}$ & $\mathbf{0 . 0}$ & $\mathbf{1 . 0}$ & $\mathbf{1 . 9}$ \\
\hline Note & \multicolumn{4}{|c|}{} & \multicolumn{6}{|c|}{} \\
\hline
\end{tabular}

Sol

\begin{tabular}{|c|c|c|c|c|c|c|c|c|c|c|c|c|c|c|c|c|c|}
\hline Variable & \multicolumn{5}{|c|}{ Colluvium depth } & \multicolumn{5}{|c|}{ Water holding capacity $(\mathrm{mm} / \mathrm{m})$} & \multicolumn{7}{|c|}{ Soil total depth } \\
\hline Classes & 0 & $5-30$ & $30-50$ & $50-80$ & $>80^{(* 3)}$ & $<100$ & $\begin{array}{c}100- \\
140\end{array}$ & $\begin{array}{c}140- \\
180\end{array}$ & $\begin{array}{c}180- \\
196\end{array}$ & $>196$ & $<35$ & $\begin{array}{c}35- \\
60\end{array}$ & $60-75$ & $75-90$ & $\begin{array}{l}90- \\
110\end{array}$ & $\begin{array}{c}110- \\
180\end{array}$ & $>180$ \\
\hline Value & -1.7 & -0.8 & 0 & 1.3 & & -0.6 & -0.3 & 0 & 0.4 & 0.6 & -3.2 & -1.1 & -0.4 & 0 & 0.8 & 1.5 & 2.2 \\
\hline
\end{tabular}

Total all variables

(1) to be adapted to local climate gradients and constraints in other regions
Soft carbonated rocks (SCR)

Total bedrock

(2) Local bedrock dip must be taken into account only in case of alternance between SCR and different other rocks, with layers from a few meters to a few tenth of meters thick, allowing roots to penetrate deeply in the soil and the rocks between unfavorable SCR layers. See in annex 2.a how to assess dip classes.

(3) With more than $80 \mathrm{~cm}$ of colluvium over SCR, particularly when the colluvium originates from an other type of rock, the general key should be used. 
Fig 6.3 Graphs for respectively all rocks but soft carbonated rocks and for SCR:

The Site Index is obtained by the projection in the graph of the total note obtained from the corresponding tool.
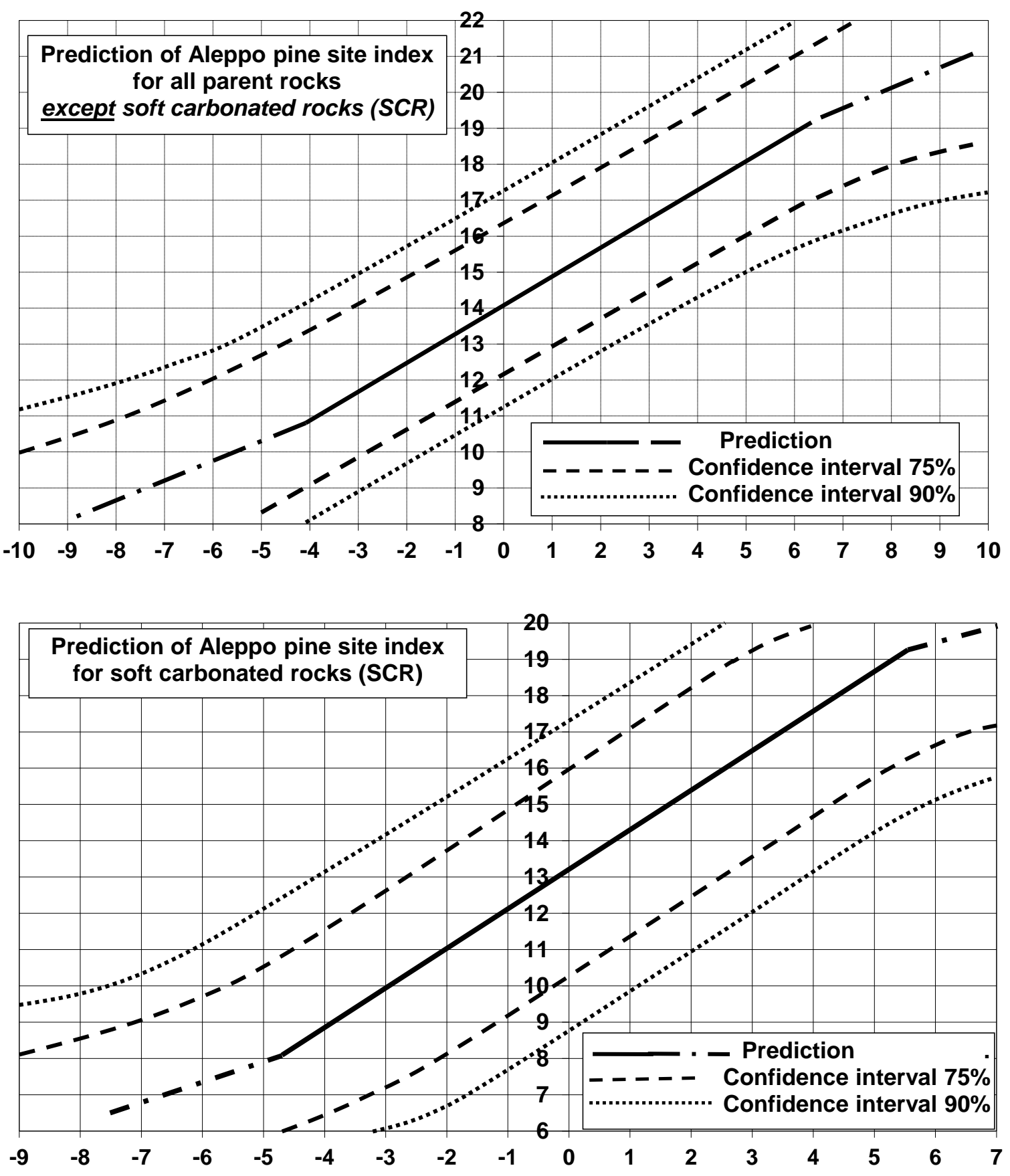


\subsection{Response to environmental variables}

\subsubsection{Climate variables}

Site index response to altitude follows (with logically a symmetric pattern) its response to temperature. But although temperature and altitude correlate well for our sample $\left(\mathrm{r}^{2}=0.65, \mathrm{p}<0.01\right)$, it was impossible to eliminate one of these two variables from the model without losing a lot of explained variance: geographic gradients (east-west, continentality, distance to the see) change their relationship particularly through (1) differences in the daily and annual span of temperature as well as its relative extremes, (2) cloudiness and air humidity patterns and, (3) the number of windy days, average wind speed and main direction. These gradients also modify the frequency of heavy snow episodes which severely damage Aleppo pine crown, thus its growth and related SI.

The optimum temperature range $\left(13.8-15.3^{\circ} \mathrm{C}\right)$ is associated with a rather long summer drought but also with a long growth season. Aleppo pine growth is favoured by high temperatures in the end of winter, i.e. January-February (Vila et al., 2008). On shallow soils with few water reserves and in Mediterranean areas, an early growth season is necessary to benefit from the water stored during previous winter months, as drought may occur since May (Thabeet et al., 2009). With a growing season split in two parts, polycyclic species as Aleppo pine can also take advantage of long and hot fall to develop new shoots (Girard et al., 2011) and produce a second flush in cambium activity, leading to a bimodal ring growth significantly increasing ring width (Pacheco et al. 2017). Budburst and shoot elongation can even occur in winter in the absence of frost (Vennetier et al, 2011).

Temperature and rainfall are inversely correlated in the study area $\left(\mathrm{r}^{2}=0.31, \mathrm{p}<0.01\right)$, but SI response is quite the same to both of them. It shows that neural networks and PLS regression correctly disentangled their respective weight and interactions in various parts of the study area. Annual and summer rainfall are optimum for values far over their average for the study area, 950-1000 $\mathrm{mm}$ and $130-140 \mathrm{~mm}$, respectively. These optimum are also far over the rainfall associated with Aleppo pine preferred altitude and temperature. So that the ideal site for both geography and climate cannot be found in the study area. The highest mean index in the eastern part of this area is explained by higher rainfall than in the western part for equivalent temperatures. SI decreases for the highest values of rainfall. In fact, these extremely rainy situations are all situated at high elevation, over $750 \mathrm{~m}$ for the study area, where Aleppo pine growth is hold back by frost and snow (Falusi et al., 1984; Girard et al., 2012; Serre, 1976, Vennetier and Hervé, 1998), in addition to the observed shortening of its life span over $600 \mathrm{~m}$ of elevation., The absolute limit in elevation is of course varying with local climate conditions in other regions.

Aspect and potential solar energy were never significant in Aleppo pine SI models, although they are important in water balance and flora composition in the same area (Vennetier et al., 2008). Close to the coast and at low elevation, southern orientation increases water stress and limits Aleppo pine growth, while at high elevation and in the colder hinterland, southern aspects limiting frost constraints are the only favourable sites. Reciprocally, northern slopes are all the more favourable to Aleppo pine than the local climate is hot and dry, and they are unfavourable in cold areas. Thus, orientation and Becker index can be considered as important (positively or negatively) only at both ends of its distribution area, and their effect added manually to improve model predictions. Relations and interactions between geographic and climatic factors are of course related to their specific combination in the study area. However, optimum values and some thresholds are probably relevant in most of Aleppo pine distribution area, as French Mediterranean region include a large proportion of the span of these factors for this distribution, except the driest and hottest parts. Some variations may occur due to the genetic adaptation of Aleppo pine to other local combination of climate and landform (Calamassi et al., 2001; Michelozzi et al., 2011).

\subsubsection{Local variables}

The weight of soil, mother rock and topography

The favorable effect of colluvial material on Aleppo pine growth appears in all analyses. A significant colluvium generally hangs together with favorable topographic positions and limited erosion. However, our sampling plan successfully limited such correlations.. Moreover, colluvial layers have a more favorable physical structure than alterites. Thanks to the movements along the slope, coarse elements overlapping in alterites, which constrains root development, are randomly distributed in colluvium. Colluvial layers are also generally less compact than their mother alterites. Finally colluvial material, especially if it is native from other parentrocks, mask partially the specific unfavorable factors of SCR as discussed in the next sub-section.

Whatever soil structure, SI increases rapidly between 20 and $80 \mathrm{~cm}$ of depth because, on shallow soils, every extra centimeter is critical for soil available water content. If the limit of 100 to $120 \mathrm{~cm}$ may be considered as sufficient for Aleppo pine good development in the study area, it corresponds also with the limit over which uncertainties on the observations are increasing. Site index also slightly increased with total soil depth between 160 and $200 \mathrm{~cm}$. As alterites rarely exceed $100 \mathrm{~cm}$ in the study area, most favorable soils for Aleppo pine seem to be structured with a $50-100 \mathrm{~cm}$ 
colluvium over the same depth or more of alterite. In such conditions, roots can rely on both good rooting conditions in superficial layers, and on long lasting water reserves in the cracks of the alterite and parent rock. This hypothesis holds with the significant role of parent-rock fissuration in the model. Indeed, this last variable is more important on pure alterite, as parent bedrocks are closer to the surface than on colluvial soils. Lapies, which presented high SIs for Aleppo pine in the study area, exemplify the important role of deep cracks and alterite pockets, compensating their high percentage of coarse fragment and rock outcrops close to the surface. Rock outcrops are rare enough on colluvial soil to have no significant role in the model. On alterites, they are good indicators of shallow and eroded soil, and thus are among strong variables.

The percentage of coarse fragments $(\mathrm{CF} \%)$ in the soil directly and proportionally reduces global soil water holding capacity. As a result, its negative impact on Aleppo pine SI is strong and linear from 20 to $95 \%$. CF\% weight is high mainly in colluvial soils in which it is highly variable, with a balanced distribution in our sample. Conversely, it is most of the time high for alteritic soils, so that its weight in the corresponding model is low due to this limited variability. However, a few high SIs could be found for very rocky soils on porous rocks: coarse fragments from these rocks may contribute to long lasting water reserves, from 1 to $20 \%$ of their volume, according to their level of alteration (Hanson et al., 1979; Witty et al., 2003).

The cover percentage of coarse fragments at soil surface (SCF) is negatively correlated with Aleppo pine SI. Yet, a dense cover by such fragments may have a positive role, limiting present erosion and evaporation. Thus, this variable is an indirect indicator of several soil conditions. On alterites, independently from erosion, it is more or less proportional to soil depth and to the percentage of these elements in the soil. When it is higher than the percentage of these elements in soil upper layers, it allows assessing past erosion rates (Birot, 1981) and related losses of fertility and soil depth... The link between erosion and SCF is confirmed by the absence of weight of SCF in the model for colluvial soils, where erosion is supposed to be absent or low.

Aleppo pine SI responds significantly to textural water holding capacity (WHC), mainly for the low $(<110 \mathrm{~mm} / \mathrm{m})$ and high values $(>160 \mathrm{~mm} / \mathrm{m})$. These high values correspond to textures where sand is absent or minority, except for the highest class $(200 \mathrm{~mm} / \mathrm{m})$. This maximum value is tied to balanced textures with nearly equivalent proportions of sand, clay and silt. Such fully balanced forest soils, rich in nutrients and rarely compact, harbour a rich biological activity with a minimum of physical constraints and are consequently densely structured in micro and macro-aggregates. Their real WHC and porosity is higher than the one determined in laboratory after soil homogenization and standard preparation, most of the time for arable soils (Teepe et al., 2003). Aleppo pine was particularly responsive to these qualities, as highlighted by higher rooting density and significantly better SI. The small improvement of SI with WHC in the lowest values of this variable (figure 3 ) corresponds to the transition between pure sands (rare in the study area) and soils with a small proportion of silt or clay. As for soil depth in its lowest class, any additional millimetre of WHC is critical for vegetation. Moreover, even a small proportion of silt or clay increases significantly soil nutrient content compared to pure sand.

Although unanimously considered in literature as adapted to carbonate soils, Aleppo pine thrives better and grows faster when decarbonatation partially or totally alleviates active lime constraints in superficial horizons, and on non-carbonate rocks. In France, Aleppo pine is rare on acidic soils where maritime pine (Pinus pinaster Aiton) was historically preferred for its faster growth, straighter bole and more abundant resin. On such soils, SI index is generally high and slightly underestimated by the model: however, computing a specific model for this special case was impossible, as the number of plots was less than 15, and useless as concerned surfaces are very limited. More resistant to drought, Aleppo pine should be considered as a possible alternative in the future at the southern and lower edges of maritime pine distribution, where this last species is at risk (El Korchani et al., 2007). As very acidic or poor leached-out soils are not found in French Mediterranean area, our model is not relevant in such situations.

\section{The specificities of soft carbonated rocks}

Aleppo pine is one of the rare tree species surviving on shallow soils developed on soft carbonated rocks (SCR) in a purely Mediterranean climate. Marls and carbonated clay-rocks present constrains to plant germination and growth which vary according to the level of alteration and may be hard to assess precisely: toxic levels of active lime, high impermeability and compacity along with a trend to be saturated and lead to root-asphyxiation when wet (Esteves et al., 2005), volume variations with water content leading to cracks and root rupture after drying, strong water retention limiting water availability for roots. Root development in unaltered SCR is almost impossible. SCR weathering alleviates these constrains (Vallauri et al., 1999), but the high erodibility of the soils developed on SCR when they are not densely vegetated generally rejuvenate them rapidly. When predicted with the general model, Aleppo pine SI on SCR shallow soils is grossly overestimated. Conversely, soils derived from SCR can be very fertile when the parent-rock have been deeply weathered for a long time, and partially decarbonated. This is demonstrated by the higher weight of 'rock outcrops in the SCR model 
compared to the non-SCR model, as an indicator of partial upper bedrock alteration. (figure 4). The model computed for SCR, although statistically significant, must be considered and handled with care, because of the rather low number of plots and an unbalanced distribution in the study area. The low weight of climate variables in this model is probably mainly due to the overwhelming physical and chemical constrains, but also partially to the incomplete distribution of plots in climate gradients of the study area. Slope angle is significant, unlike the three other models, because of the high sensibility of SCR to erosion (Oostwoud Wijdenes and Ergenzinger, 1998). Coarse fragments are irrelevant for this type of rocks. Colluvium depth is dominant because any type of colluvium, but particularly those coming from other parent-rocks, hide the constraints of SCR. With more than $80 \mathrm{~cm}$ of colluvium, a site on SCR can be assessed with the general model. The importance of dip in the model for SCR shows that any hard bedrock intercalated within SCR improves their suitability for Aleppo pine. Particularly when dip angle is high, water can take advantage of these other rocks to penetrate soil in depth. Roots following these beds benefit from the high water holding capacity of SCR at the interface.

\section{Legacies of past land uses}

A long lasting impact of land use and particularly agriculture on the environment (Dupouey et al., 2002) is demonstrated by Aleppo pine growth. Former cultivated terraces, even when they have nearly disappeared, increase SI index by about two meters. Traces of old fields (ploughing lines, stone heaps and walls) are also associated with a positive impact. Erosion control, soil retention and higher infiltration rates thanks to terraces and walls, remnant phosphorus and nitrogen higher rates, a lower compacity of superficial layers due to ploughing, lower evaporation under stone piles and slower wind at soil surface near the walls, may explain together the global improvement of the environment. The weight of past land use is mainly visible on colluvial soils: terraces and cultures were in priority laid out on good soils and avoided when possible superficial and stony alterites. On initially shallow soils, terraces artificially fixed a colluvium with time, or soil was brought from the neighbourhoods. On the other hand, cultivated areas are opposed with former grazing land which represents the large majority of the study area, most of the time degraded by millennia of overgrazing, fire and erosion (Blondel and Aronson, 1999). The scattered stone heaps and loose wall networks of these extensive pastures are not sufficient to improve significantly their fertility level. So that the positive impacts of past cultivation, and of related land transformation practices, may be highlighted and statistically magnified by the contrast with the negative impacts of other traditional landuses.

\section{The key role of water balance}

The relative weight of local variables for Aleppo pine may be relevant anywhere: as in the bioclimatic model calibrated on the flora of many of these plots (Vennetier et al., 2008), it highlights their contribution to water balance. Water availability is the main limiting factor for tree growth in Mediterranean regions, as confirmed for Aleppo pine by Olivar et al. (2014). This explains the importance of topography at both local and landscape scales, which is always among dominant variables whatever the model. Topography directly contributes to water balance through water flows control and indirectly drives many important soil variables (depth, colluvium, texture, past land uses). Consistently, topography appears as a key factor in forest dynamics with increasing drought in Spain (José Vidal-Macua et al., 2017).

One missing factor in this study is soil richness for the main nutrients, which was never significant, as the study area does not include very poor or very acidic soils.

\subsubsection{Towards a new balance between local and climate variables with climate change?}

As a foretaste of the climate forecasted by RCP4.5 scenario of IPCC 2013 for the middle of the $21^{\text {st }}$ century (Christensen et al., 2013; Kirtman et al., 2013), the eastern part of the study area experienced during the 1998-2008 decade, an exceptionally hot and dry spell. As a result, Aleppo pine current mortality doubled (French-Forest-HealthDepartment, 2003-2008) while its productivity dropped, and its crown development was seriously altered (Girard et al., 2012), showing that critical thresholds of water stress were passed. As a sign of what may happen in the future in southern France and in regions with a similar climate in southern Europe, Aleppo pine has already been suffering for decades from significant growth reduction and dieback in Tunisia (El Khorchani et al., 2007). This doesn't challenge our models in the short term: within local variables, the relative weight may not significantly change, except for geological variables allowing root systems to reach deep water reserves (cracks in bedrocks, dip angle) which increasing role with aridification was recently underlined (Sarris et al., 2013).

However, the spatial distribution of fertility classes in the landscapes will be submitted to northward and elevation shifts with higher temperatures and a drier growing season. Such local changes are forecasted in other types of biomes with a local reduction of the age-height site index (Sharma et al. 2015Dip angle classes).

To some extent, the relative weight of climate variables would probably have to be increased in our practical tool when drought stress becomes extremely limiting, which may happen in the study area before the end of the $21^{\text {st }}$ century. For the same 
reasons, the balance between climate and local variables should be reassessed if our models and tool are used in regions which climate is out of the range of the one of the study area.

Aside tree growth, reproduction is an important function contributing to the presence and persistence of a species in a specific area. Our study didn't tackle reproduction, but several authors specifically addressed this problem. Ayari et al (2011a) found variations of cone and seed production along geographical and elevation gradients, with a better production in more humid areas. Girard et al. (2012) showed that cone production could be severely reduced after 4 to 5 years of exceptional drought, but recovered rapidly.

One of the challenges in terms of forest management will be to maintain tree growth and limit mortality in a more arid climate. Olivar et al. (2014) showed that soil water availability during the growing season was the main driver of Aleppo pine growth, and that thinnings can contribute to release the effects of water limitations (Giuggiola et al., 2016). Many species are positively affected by thinnings in a drought context (Sohn et al., 2016). However, this impact depends on other components of forest structure: thinnings may favour the development of dense undergrowth which water demand offsets the water savings of a reduced canopy (Gavinet et al., 2015).

Aleppo pine is still not at risk in France, neither for survival for growth nor for reproduction, as it is far from its bioclimatic limits, particularly from those observed in Northern Africa and Israel. In southeastern Spain, José Vidal-Macua et al. (2017) showed that it has gained ground against broadleaved evergreen species in the last decades. Even with a reduced growth, it remains highly competitive (Vila et al. 2008).

\section{Acknowledgments}

This work was funded by the French Ministry for Agriculture Food and Fisheries, the National Research Agency (project DROUGHT+ ${ }^{\circ}$ ANR06-VULN-003-04), the Provence-Alpes-Côte d'Azur region and Irstea.

\section{Conclusion and prospects}

This paper offers a new and deep insight in the ecology of Aleppo pine. Assessing precisely Aleppo pine adaptation and potential productivity requires a thorough investigation of site conditions, including climate, soil characteristics down to deep layers and parent-rock, and topography on several scales.

When summed together, local factors are more important than climatic factors for Aleppo pine growth in the study area. The French Mediterranean climate is not very limiting for Aleppo pine growth. Even at the driest and hottest places, deep and good soils and a favourable local topography allow its growth to reach at least the mean fertility class. However, frost and snow hold it back at high elevation and northward, while the increase in humidity shortens its lifetime. Moreover, with climate change acceleration, the influence of rainfall and temperature factors may increase, as worsening water stress will no longer be sufficiently compensated by local conditions.

As the span of climate conditions in south-eastern France includes most of those found in Aleppo pine distribution area, except the driest and hottest ones found in Northern Africa and in some Mediterranean islands, this study could be easily used or adapted in all concerned countries. In countries where Aleppo pine climate/growth relations where already established, this study can help improving forest site assessment.
The authors are indebted to many technicians and students who contributed together to more than 200 days of field work during several years, particularly Olivier Chandioux, Roland Estève, Fabien Brochiéro and Yaacoub Nassif. They thank Bernard Prevosto, and two anonymous reviewers, whose detailed and constructive comments helped improving the manuscript.

The authors declare no competing interests. 


\section{References}

Achenar M. ; Lepart J. ; Debussche M. (1984) La colonisation des friches par le pin d'Alep (Pinus halepensis Miller) en Languedoc méditerranéen. Acta oecol Oecol Plant 5 (19):179-189.

Allen C.D., Macalady A.K., Chenchouni H., Bachelet D., Mcdowell N., Vennetier M., Kitzberger T., Rigling A., Breshears D.D., Hogg E.H., et al., 2010. A global overview of drought and heat-induced tree mortality reveals emerging climate change risks for forests, For. Ecol. Manag., (259) 4: 660-684.

Antoine P. ; Giraud A. ; Meunier M. ; Van Asch T. (1995) Geological and geotechnical properties of the "Terres Noires" in southeastern France: weathering, erosion, solid transport and instability. Engineer Geol 40:223-234.

Ayari A., Moya D., Rejeb M.N., Ben Mansoura A., Albouchi A., De Las Heras J., Fezzani T., Henchi B., 2011 a. Geographical variation on cone and seed production of natural Pinus halepensis Mill. forests in Tunisia, J. Arid Environ., (75) 5: 403-410

Ayari A., Moya D., Rejeb M.N., Ben Mansoura A., Garchi S., De Las Heras J., Hanchi B. (2011b) Alternative sampling methods to estimate structure. Forest systems 20 (3): 348-360

Backer T.R. ; Phillips O.L. ; Malhy Y. ; Almeida S. ; Arroyo L. ; A. D.F. ; Erwin T. ; Higuchi N. ; T.J. K. ; S.G. L. ; Al. E. (2004) Increasing biomass in Amazonian forest plots. Philos Trans Royal Soc London Series B-Biol Sci 359 (1443):353-365.

Barbéro M. ; Loisel R. ; Quézel P. ; Richardson D.M. ; Romane F. (1998) Pines of the mediterranean basin. In: Richardson D.M. ed. Ecology and biogeography of Pinus, Cambridge University Press, Cambridge pp 153-170.

Becker M. (1984) Indices de climat lumineux selon la pente et l'exposition pour les latitudes de 40 à $50^{\circ}$, Bulletin d'Ecologie, (15) 4: 239-252.

Becker M. ; Bert G.D. ; Bouchon J. ; Picard J.F. ; Ulrich E. (1994) Tendances à long terme observées dans la croissance de divers feuillus et résineux du Nord-Est de la France depuis le milieu du 19e siècle. Rev For Fr XLVI (4):335341.

Berges L. ; Gegout J.C. ; Franc A. (2006) Can understory vegetation accurately predict site index? A comparative study using floristic and abiotic indices in sessile oak (Quercus petraea Liebl.) stands in northern France. Ann For Sci $63(1): 31-42$.

Birot P. (1981) Les processus d'érosion à la surface des continent. Masson, Paris, 607 p.

Blondel J. ; Aronson J. (1999) Biology and wildlife of the Mediterranean region. Oxford University Press, Oxford 328 p.

Borghetti M. ; Cinnirella S. ; Magnani F. ; Saracino A. (1998) Impact of long-term drought on xylem embolism and growth in Pinus halepensis Mill. Trees Struct Funct 12 (4):187-195.

Bueis T., Bravo F., Pando V., Turrion M.B., 2017. Site factors as predictors for Pinus halepensis Mill. productivity in Spanish plantations, Ann. For. Sci., (74) 1.

Calamassi, R., Della Rocca, G., Falusi, M., Paoletti, E., Strati,S. (2001) Resistance to water stress in seedlings of eight European provenances of Pinus halepensis Mill. - Ann. Forest. Sci. 58:663-672.

Cannel M.G.R. (1998) Relative importance of increasing atmospheric CO2, N deposition and temperature in promoting European forest growth. In: Karjalainen T. ; Spiecker H., et al. ed. EFI Proceedings vol. 27, International Seminar "Causes and consequences of accelerating tree growth in Europe", EFI \& ECOFOR, Joensuu, pp. 25-42

Christensen J.H., Krishna Kumar K., Aldrian E, An S.-I., Cavalcanti I.F.A., de Castro M., Dong W., Goswami P., Hall A., Kanyanga J.K., Kitoh A., Kossin J., Lau N.-C., Renwick J., Stephenson D.B., Xie S.-P., Zhou T. (2013) Climate Phenomena and their Relevance for Future Regional Climate Change. In: Cli-mate Change 2013: The Physical Science Basis. Contribution of Working Group I to the Fifth Assessment Report of the Intergovernmental Panel on Cli-mate Change [Stocker, T.F., D. Qin, G.-K. Plattner, M. Tignor, S.K. Allen, J. Boschung, A. Nauels, Y. Xia, V. Bex and P.M. Midgley (eds.)]. Cambridge University Press, Cambridge, United Kingdom and New York, NY, USA, p. 1217-1308

Cook E.R. ; Bird T. ; Peterson M. ; Barbetti ; Buckley M. ; D'arrigo B.R. ; Francey R. ; Tans P. (1991) Climatic change in Tasmania inferred from a 1089-year tree-ring chronology of Huon Pine. Science 253:1266-1268.

Couhert B. ; Duplat P. (1993) Le pin d'Alep dans la région Provence Alpes Côte d'Azur proposition pour une sylviculture et un modèle de production. Bull Techn de l'ONF, Vol 25.

Cramer R.D.I. ; Bunce J.D. ; Paterson D.E. ; Frank I.E. (1988) Crossvalidation, bootstrapping, and partial least square compared with multiple regression in conventional QSAR studies. Quantit Struct Activ Relatsh 7:18-25.

D'arrigo R.D. ; Buckley B.M. ; Cook E.R. ; Wagner W.S. (1996) Temperature-sensitive tree-ring width chronologies of pink pine (Halocarpus biformis) from Stewart Island, New Zealand. Palaeogeogr Palaeoclimat Palaeoecol 119 (3-4):293-300. 
Daskalakou E.N. ; Thanos C.A. (1996) Aleppo pine (Pinus halepensis) postfire regeneration: The role of canopy and soil seed banks. Int J Wildland Fire 6 (2):59-66.

David-Schwartz R., Paudel I., Mizrachi M., Delzon S., Cochard H., Lukyanov V., Badel E., Capdeville G., Shklar G., Cohen S., 2016. Indirect Evidence for Genetic Differentiation in Vulnerability to Embolism in Pinus halepensis, Frontiers in Plant Science, (7) 768.

De Luis M., Čufar K., Di Filippo A., Novak K., Papadopoulos A., Piovesan G., Rathgeber C.B.K., Raventós J., Saz M.A., Smith K.T., 2013. Plasticity in dendroclimatic response across the distribution range of Aleppo pine (Pinus halepensis), PLoS One, (8) 12.

Diaz-Maroto I.J. ; Vila-Lameiro P. ; Diaz-Maroto M.C. (2006) Autecology of sessile oak (Quercus petraea) in the northwest Iberian Peninsula. Scand J For Res 21 (6):458-469.

Dubravac T. ; Barcic D. ; Spanjol Z. ; Vrbek B. ; Roth V. ; Dekanic S. (2006) Natural reforestation of Aleppo Pine (Pinus halepensis Mill.) stands after forest fire. For Ecol and Manag 234 (Supplement 1):S206.

Dupouey J.L. ; Dambrine E. ; Laffite J.D. ; Moares C. (2002) Irreversible impact of past land use on forest soil and biodiversity. Ecology 83 (11):2978-2984.

Eichhorn F. (1904) Beziehungen zwischen Bestandshöhe und bestandsmasse. Algemeine Forst. und Yagt-Zeitung (80:4549.

El Khorchani A., Gadbin-Henry C., Bouzid S., Khaldi A., 2007. Impact de la sécheresse sur la croissance de trois espèces forestières en Tunisie (Pinus halepensis Mill., Pinus pinea L. et Pinus pinaster Sol.), Sécheresse, (18) 2: 113-121.

Esteves M. ; Descroix L. ; Mathys N. ; Lapetite J. (2005) Soil hydraulic properties in a marly gully catchment (Draix, France). Catena

Falusi, M., Calamassi, R., Tocci, A. (1984) [Frost resistance in Pinus halepensis Mill., Pinus brutia Ten. and Pinus eldarica Medw.] - Atti Soc. Tosc. Sci. Nat. - Mem., serie B: 91. [In Italian.]

French-Forest-Health-Department (2003-2008) Annual reports. http://www.agriculture.gouv.fr/spip/ressources.themes.foretbois.santedesforets_r314.html. Departement Santé des Forêts, Paris. Accessed Sept 2017

Ganatsas P., Thanasis G. (2010) Pinus halepensis invasion in Pinus pinea habitat in Strofylia forest (Site of NATURA 2000 network), southern Greece, Journal for Nature Conservation, (18) 2: 106-117.

Gaucherel C. ; Campillo F. ; Misson L. ; Guiot J. ; Boreux J.J. (2008) Parameterization of a process-based tree-growth model: Comparison of optimization, MCMC and Particle Filtering algorithms. Envir Model Softw 23 (1011):1280-1288.

Gavinet J., Vilagrosa A., Chirino E., Granados M.E., Vallejo V.R., Prevosto B., 2015. Hardwood seedling establishment below Aleppo pine depends on thinning intensity in two Mediterranean sites, Ann. For. Sci., (72) 8: 999-1008.

Geppa-Sescpf (1981) Synthèse des travaux de la commission "Cartographie". INRA, 25 p.

Girard F., Vennetier M., Ouarmim S., Caraglio Y., Misson L. (2011) Polycyclism, a fundamental tree growth process, decline with recent climate change. The example of Pinus halepensis Mill. in Mediterranean France. TreesStructure and Function 25(2) 311-322

Girard F., Vennetier M., Guibal F., Corona C., Ouarmim S., Herrero A. (2012) Pinus halepensis Mill. crown development and fruiting declined with repeated drought in Mediterranean France. European Journal of Forest Research 131(4) 919-931.

Giuggiola A., Ogée J., Rigling A., Gessler A., Bugmann H., Treydte K., 2016. Improvement of water and light availability after thinning at a xeric site: Which matters more? A dual isotope approach, New Phytol., (210) 1: 108-121.

Giuggiola A., Zweifel R., Feichtinger L.M., Vollenweider P., Bugmann H., Haeni M., Rigling A., 2018. Competition for water in a xeric forest ecosystem - Effects of understory removal on soil micro-climate, growth and physiology of dominant Scots pine trees, For. Ecol. Manag., (409): 241-249.

Glatzel G. (1998) Historic forest use and its possible implication to recently accelerated tree growth in Central Europe. In: Karjalainen T. ; Spiecker H., et al. ed. EFI Proceedings vol. 27, International Seminar "Causes and consequences of accelerating tree growth in Europe", EFI \& ECOFOR, Joensuu , pp. 65-74.

Guiot J. (1991) Methods and programs of statistics for palaeoclimatology and palaeoecology. Guiot, J. \& Labeyrie, L. ed., INSU, Paris, Marseille, 258 p.

José Vidal-Macua J., Ninyerola M., Zabala A., Domingo-Marimon C., Pons X., 2017. Factors affecting forest dynamics in the Iberian Peninsula from 1987 to 2012. The role of topography and drought, For. Ecol. Manag., (406): 290306.

Hägglund B. (1981) Evaluation of forest site productivity. Forestry Abstract, 42:515-527. 
Hanson C.T. ; Blevins R.L. (1979) Soil-Water in Coarse Fragments. Soil Sci Soc Am J 43 (4):819-820.

Kirtman, B, Power ., S.B., Adedoyin J.A., Boer G.J., Bojariu R., Camilloni I., Doblas-Reyes F.J., Fiore A.M., Kimoto M., Meehl G.A., Prather M., Sarr A., Schär C., Sutton R., van Oldenborgh G.J., Vecchi G., Wang H.J. (2013: Nearterm Climate Change: Projections and Predictability. In: Climate Change 2013) The Physical Science Basis. Contribution of Working Group I to the Fifth Assessment Report of the Intergovernmental Panel on Climate Change [Stocker, T.F., D. Qin, G.-K. Plattner, M. Tignor, S.K. Allen, J. Boschung, A. Nauels, Y. Xia, V. Bex and P.M. Midgley (eds.)]. Cambridge University Press, Cambridge, United Kingdom and New York, NY, USA.

Le Houérou H.N. (2005) Atlas de la répartition de 250 espèces-clés dans le bassin méditerranéen. Le Houérou ed., Montpellier, $220 \mathrm{p}$.

Maestre F.T. ; Cortina J. (2004) Are Pinus halepensis plantations useful as a restoration tool in semiarid Mediterranean areas? For Ecol and Manag 198 (1-3):303-317.

Michelozzi M., Loreto F., Colom R., Rossi F., Calamassi R. (2011) Drought responses in Aleppo pine seedlings from two wild provenances with different climatic features, Photosynthetica, (49) 4: 564-572.

Misson L. ; Rathgeber C. ; Guiot J. (2004) Dendroecological analysis of climatic effects on Quercus petraea and Pinus halepensis radial growth using the process-based MAIDEN model. Can J For Res 34 (4):888-898.

Ne'eman G. ; Trabaud L. (2000) Ecology, biogeography and management of Pinus halepensis and Pinus brutia forest ecosystems in the Mediterranean Basin. Backuys Publishers, Leiden - The Netherland.

Novak K., De Luis M., Saz M.A., Longares L.A., Serrano-Notivoli R., Raventós J., Čufar K., Gričar J., Di Filippo A., Piovesan G., Rathgeber C.B.K., Papadopoulos A., Smith K.T., 2016. Missing rings in pinus halepensis - The missing link to relate the tree-ring record to extreme climatic events, Frontiers in Plant Science, (7) MAY2016.

Olarieta J.R., Usón A., Rodríguez R., Rosa M., Blanco R., Antúnez M., 2000. Land requirements for Pinus halepensis Mill. growth in a plantation in Huesca, Spain, Soil Use Manag., (16) 2: 88-92.

Olivar J., Bogino S., Rathgeber C., Bonnesoeur V., Bravo F., 2014. Thinning has a positive effect on growth dynamics and growth-climate relationships in Aleppo pine (Pinus halepensis ) trees of different crown classes, Ann. For. Sci., (71) 3: 395-404.

Olivar J., Bogino S., Spiecker H., Bravo F., 2012. Climate impact on growth dynamic and intra-annual density fluctuations in Aleppo pine (Pinus halepensis) trees of different crown classes, Dendrochronologia, (30) 1: 35-47

Oostwoud Wijdenes D.J., Ergenzinger P., 1998. Erosion and sediment transport on steep marly hillslopes, Draix, HauteProvence, France: An experimental field study, CATENA, (33) 3-4: 179-200.

Pacheco A., Camarero J.J., Ribas M., Gazol A., Gutierrez E., Carrer M., 2017. Disentangling the climate-driven bimodal growth pattern in coastal and continental Mediterranean pine stands, Sci. Total Environ.: in press.

Pasho E., Julio Camarero J., Vicente-Serrano S.M. (2012) Climatic impacts and drought control of radial growth and seasonal wood formation in Pinus halepensis, Trees - Structure and function: 1-12.

Pausas J.G. ; Ribeiro E. ; Vallejo R. (2004) Post-fire regeneration variability of Pinus halepensis in the eastern Iberian Peninsula. For Ecol and Manag 203 (1-3):251-259.

Pianka E.R. ; Sven Erik J. ; Brian F. (2008) Autecology. In: Encyclopedia of Ecology, Academic Press, Oxford, p. $285-$ 287.

Prieto P. ; Penuelas J. ; Llusia J. ; Asensio D. ; Estiarte M. (2009) Effects of long-term experimental night-time warming and drought on photosynthesis, Fv/Fm and stomatal conductance in the dominant species of a Mediterranean shrubland. Acta Physiol Plant 31 (4):729-739.

Quézel P. ; Médail F. (2003) Ecologie et biogéographie des forêts du bassin méditerranéen. Elsevier, Paris, 571 p.

R Development Core Team (2010), R: A Language and Environment for Statistical Computing. Vienna, Austria : the R Foundation for Statistical Computing. ISBN: 3-900051-07-0. Available online at http://www.R-project.org/.

Rathgebber C. ; Blanc L. ; Ripert C. ; Vennetier M. (2004) Modélisation de la croissance en hauteur du pin d'Alep (Pinus halepensis Mill.) en région méditerranéenne française. Ecol Médit 30 (2):205-218.

Rathgeber C. ; Nicault A. ; Kaplan J.O. ; Guiot J. (2003) Using a biogeochemistry model in simulating forests productivity responses to climatic change and [CO2] increase: example of Pinus halepensis in Provence (southeast France). Ecol Model 166 (3):239-255.

Richards F.J. (1959) A flexible growth function for empirical use. J Exp Bot 10:290-300.

Rincon A. ; Ruiz-Diez B. ; Fernandez-Pascual M. ; Probanza A. ; Pozuelo J.M. ; Felipe M.R.D. (2006) Afforestation of degraded soils with Pinus halepensis Mill.: Effects of inoculation with selected microorganisms and soil amendment on plant growth, rhizospheric microbial activity and ectomycorrhizal formation. App Soil Ecol 34 (1):42-51. 
Rivas-Martínez, Salvador, Sánchez-Mata, Daniel, and Costa, Manuel, 2004, Synoptical Worldwide Bioclimatic Classification System: Madrid, University Complutense of Madrid. Accessed Oct. 2017 at: http://www.globalbioclimatics.org/book/bioc/tabla3.htm

Rolland C. ; Petitcolas V. ; Michalet R. (1998) Changes in radial tree growth for Picea abies, Larix decidua, Pinus cembra and Pinus uncinata near the alpine timberline since 1750. Trees Struct Funct 13 (1):40-53.

Sarris D., Christodoulakis D., Korner C. (2011) Impact of recent climatic change on growth of low elevation eastern Mediterranean forest trees, Clim. Change, (106) 2: 203-223.

Sarris D., Siegwolf R., Körner C. (2013) Inter- and intra-annual stable carbon and oxygen isotope signals in response to drought in Mediterranean pines, Agric. For. Meteorol., (168) 0: 59-68.

Serre F. (1976) Les rapports de la croissance et du climat chez le pin d'Alep. Acta oecol plant, 11:3.

Simioni G., Marie G., Huc R., 2016. Influence of vegetation spatial structure on growth and water fluxes of a mixed forest: Results from the NOTG 3D model, Ecol. Model., (328): 119-135.

Sharma M., Subedi N., Ter-Mikaelian M., Parton J., 2015. Modeling climatic effects on stand Height/Site index of plantation-grown jack pine and black spruce trees, For. Sci., (61) 1: 25-34.

Skovsgaard J.P. ; Jeffery B. (2004) Forest Measurements. In: Encyclopedia of Forest Sciences, Elsevier, Oxford, p. 550566.

Skovsgaard J.P. ; Vanclay J.K. (2008) Forest site productivity: a review of the evolution of dendrometric concepts for even-aged stands. Forestry 81 (1):12-31.

Sohn J.A., Saha S., Bauhus J., 2016. Potential of forest thinning to mitigate drought stress: A meta-analysis, For. Ecol. Manag., (380): 261-273.

Spiecker H. ; Mielikäinen K. ; Köhl M. ; Skovsgaard J.P. (1996) Growth trends in European forests: studies from 12 countries. Springer-Verlag, Heidelberg, 372 p.

Szeicz J.M. (1997) Growth trends and climatic sensitivity of trees in the North Patagonian rain forest of Chile. Can J For Res 27 (7):1003-1014.

Tatoni T. ; Magnin F. ; Bonin G. ; Vaudour J. (1994a) Secondary Successions on Abandoned Cultivation Terraces in Calcareous Provence .1. Vegetation and Soil. Acta Oecol Int J Ecol 15 (4):431-447.

Tatoni T. ; Roche P. (1994b) Comparison of Old-Field and Forest Revegetation Dynamics in Provence. J Veget Sci 5 (3):295-302.

Teepe R. ; Dilling H. ; Beese F. (2003) Estimating water retention curves of forest soils from soil texture and bulk density. J Plant Nutr Soil Sci Zeitschrift Fur Pflanzenernahrung Und Bodenkunde 166 (1):111-119.

Thabeet A. ; Vennetier M. ; Gadbin-Henry C. ; Denelle N. ; Roux M. ; Caraglio Y. ; Vila B. (2009) Response of Pinus sylvestris L. to recent climate change in the French Mediterranean region. Trees Struct Funct 28 (4):843-853.

Trasobares A. ; Tome M. ; Miina J. (2004) Growth and yield model for Pinus halepensis Mill. in Catalonia, north-east Spain. For Ecol and Manag 203 (1-3):49-62.

Vallauri D.R., Aronson J., Barbero M., 2002. An analysis of Forest Restauration on Badlands in the Southwestern Alps, Restor. Ecol., (10) 1: 16-26.

Vennetier M., Girard F., Didier C., Ouarmim S., Ripert C., Esteve R., Martin W., Ndyaye A., Misson L. (2011) Adaptation phénologique du pin d'Alep au changement climatique. Forêt Méditerranéenne, 32(2) 151-167.

Vennetier M. ; Hervé J.C. (1998) Short and long term evolution of Pinus halepensis (Mill.) height growth in Provence (France) and its consequences for timber production. In: Karjalainen T. ; Spiecker H., et al. ed. EFI Proceedings vol. 27, International Seminar "Causes and consequences of accelerating tree growth in Europe", EFI \& ECOFOR, Joensuu, pp. 253-265.

Vennetier M., Ripert C., Brochiero F., Rathgeber C., Nassif Y., Chandioux O., 2010. Evaluation de la croissance du pin d'Alep en région méditerranéenne française, Revue Forestière Française, (LXXII) 5: 503-524.

Vennetier, M., Ripert, C., Maillé, E., Blanc, L., Torre, F., Roche, P., Tatoni, T., Brun, J.-J., 2008. A new bioclimatic model calibrated with flora for Mediterranean forested areas, Annals Forest Science, (65) 711.

Verkaik I. ; Espelta J.M. (2006) Post-fire regeneration thinning, cone production, serotiny and regeneration age in Pinus halepensis. For Ecol and Manag 231 (1-3):155-163.

Vila B. ; Vennetier M. ; Ripert C. ; Chandioux O. ; Liang E. ; Guibal F. ; Franck T. (2008) Has global change induced opposite trends in radial growth of Pinus sylvestris and Pinus halepensis at their bioclimatic limit? The example of the Sainte-Baume forest (south-east France). Ann For Sci 65 - 709

Witty J.H. ; Graham R.C. ; Hubbert K.R. ; Doolittle J.A. ; Wald J.A. (2003) Contributions of water supply from the weathered bedrock zone to forest soil quality. Geoderma 114 (3-4):389-400. 
Vennetier, M.; Ripert, C., Rathgeber, C. - 2018. Autecology and growth of Aleppo pine (Pinus halepensis Mill.): a comprehensive study in France. Forest Ecology and Management. 413 (2018) 32-47. https://doi.org/10.1016/j.foreco.2018.01.028

Zalba S.M. ; Cuevas Y.A. ; Boo R.M. (2008) Invasion of Pinus halepensis Mill. following a wildfire in an Argentine grassland nature reserve. J Envir Manag 88 (3):539-546. 


\section{Appendices}

\section{Appendix 1: Height growth modelling}

As most sampled stands were irregular and unevenaged, site index was computed tree by tree (tree SI) with the height growth model for the base age of 70 years, and plot SI was calculated as the average of concerned individual tree SI. Sampled trees were 70 years-old in average, which is also the recommended logging age for Aleppo pine on medium to high fertility sites in French managed forests (Couhert and Duplat, 1993). As tree height growth is irregular before 30 years, and the number of studied trees limited over 120 years, the use of the growth curves is only perfectly accurate between these two limits (figure 2, Vennetier et al., 2010).

Equation 2: height growth model inversed to calculate tree SI.

$$
S I_{i}=h_{i} \cdot\left[\frac{1-\exp \left(-0.021 \times a g e_{r e f}\right)}{1-\exp \left(-0.021 \cdot \text { age }_{i}\right)}\right]^{1.5385}
$$

were

* $\mathbf{S I}_{\boldsymbol{i}}:$ SI for tree $\boldsymbol{i}=$ estimated tree height at 70 years,

$* \mathbf{h}_{\boldsymbol{i}}$ and $\mathbf{a g e} \boldsymbol{i}$ : present measured height and age of tree $\boldsymbol{i}$,

* Age $_{\text {ref. }}=$ reference age, 70 years for this study

* $\mathbf{- 0 . 0 2 1}$ et 1.5385: general parameters fitted to the whole sample.

As demonstrated by a previous study in Provence (Vennetier et al., 1998), a significant increase of Aleppo pine height growth occurred in Southern France during the $20^{\text {th }}$ century. This is highlighted by the significant difference in height -age SI for trees of different age classes within unevenaged plots. Following the same protocol, and thanks to the homogeneity of site conditions within each plot, we computed this acceleration as the slope of the regression between differences of SI and differences in age of concerned individual trees (equation 3 and figure 7).

Equation 3: height growth acceleration (a)

$\left(\mathbf{S I}_{i j}-\mathbf{S I}_{j}\right)=\mathbf{a} *\left(\right.$ age $\left._{i j}-\mathbf{a g e}_{j}\right)$ were

$* \mathbf{S I}_{i j}$ and $\mathbf{a g e}_{i j}=\mathrm{SI}$ and age of each tree i in plot $\mathrm{j}$, respectively,

* $\mathbf{S I}_{j}$ and $\mathbf{a g e}_{j}=$ mean height and mean age of all measured trees of plot $\mathrm{j}$, respectively.

$* \mathbf{a}=$ height growth acceleration in the concerned period

The acceleration computed for the $20^{\text {th }}$ century was $0.041 \mathrm{~m}^{*}$ year $^{-1}\left(\mathrm{r}^{2}=0.26, \mathrm{P}<0.01\right.$, figure 7$)$.

Fig.7 Intra-plot SI variation according to tree age, showing Aleppo pine height growth acceleration in the $20^{\text {th }}$ century

Tree SI were thus age-dependent, underestimated by older trees and overestimated by younger ones. They were corrected according to the difference between tree age and the reference age (70) with equation 4.

Equation 4: correction of tree SI according to tree age (same meaning of the symbols as equation 2): $\mathbf{S I}_{i j \text { cor }}=\mathbf{S I}_{i j}+\left(\right.$ Age $\left._{i j}-\mathbf{7 0}\right) * \mathbf{0 . 0 4 1}$

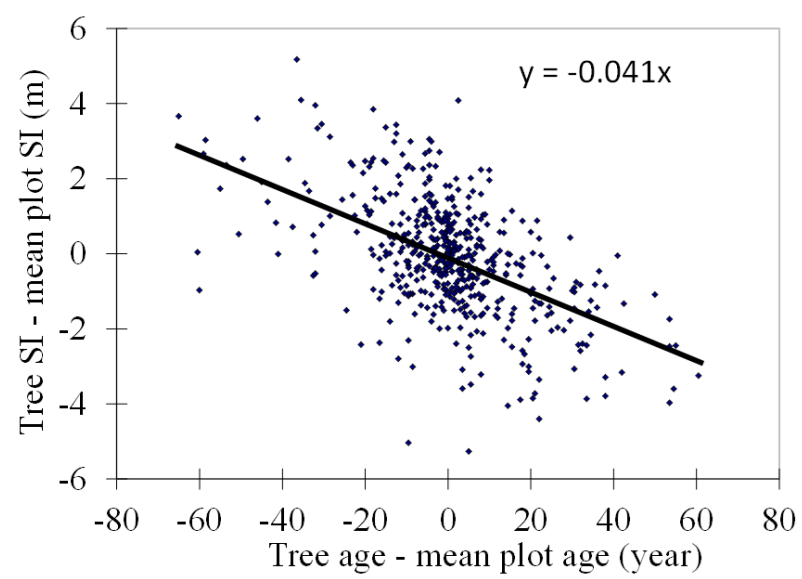

The final plot SI (SI $\mathbf{I}_{\mathbf{j c o r}}$ ) was calculated as the average of $\mathbf{S I}_{\boldsymbol{i j} \text { cor. }}$. We chose to split site index in five fertility classes with an equal span of $3.35 \mathrm{~m}$ (figure 2). 


\section{Appendix 2: Classes of some used variables}

\section{A2.a: Dip angle classes}

For dip angle parallel to form lines and on flat ground, limits between the 3 classes $(1=$ favourable, $0=$ neutral and $1=$ unfavourable) are $15^{\circ}$ and $35^{\circ}$ from horizontal.

When the slope is significant, table 3 gives the equations to calculate these limits upslope and downhill for dip perpendicular to form lines, and limits of classes with a $5^{\circ}$ span. Figure 8 illustrates the dip variable with the example of a $30^{\circ}$ slope.

The final note is obtained by the sum of dip classes, parallel and perpendicular to form lines, and varies from -2 to $+2$

Table 3: Limits of dip angle classes. Equations of the limits for favourable, neutral and favourable situations upslope and downhill according to slope angle. $y=$ dip angle with horizontal, $x=$ slope angle with horizontal ( $x$ and $y$ in degree). $-1=$ unfavourable; $0=$ neutral; 1 = favourable. These equations are valid for dip angle parallel and perpendicular to form lines and on flat ground.

\section{Limit between dip classes}

\begin{tabular}{|c|c|c|c|c|c|}
\hline \multicolumn{3}{|c|}{ Upslope } & \multicolumn{3}{|c|}{ Dowsn slope } \\
\hline limit $-1 / 0$ & \multirow{2}{*}{\multicolumn{2}{|c|}{$\begin{array}{l}y=0.8333 x-15 \\
y=0.6667 x-45\end{array}$}} & limit $-1 / 0$ & \multirow{2}{*}{\multicolumn{2}{|c|}{$\begin{array}{c}y=0.75 x+15 \\
y=0.5 x+35\end{array}$}} \\
\hline limit $0 / 1$ & & & limit 0 / 1 & & \\
\hline \multirow{2}{*}{$\begin{array}{c}\text { Ground slope } \\
\left({ }^{\circ}\right)\end{array}$} & \multicolumn{2}{|c|}{ Upslope } & \multirow{2}{*}{$\begin{array}{c}\text { Ground } \\
\text { slope }\left(^{\circ}\right)\end{array}$} & \multicolumn{2}{|c|}{ Downslope } \\
\hline & $-1 / 0$ & $0 / 1$ & & $-1 / 0$ & $0 / 1$ \\
\hline 0 & -15.0 & -35.0 & 0 & 15 & 35 \\
\hline 5 & -10.8 & -31.7 & 5 & 18.75 & 37.5 \\
\hline 10 & -6.7 & -28.3 & 10 & 22.5 & 40 \\
\hline 15 & -2.5 & -25.0 & 15 & 26.25 & 42.5 \\
\hline 20 & 1.7 & -21.7 & 20 & 30 & 45 \\
\hline 25 & 5.8 & -18.3 & 25 & 33.75 & 47.5 \\
\hline 30 & 10.0 & -15.0 & 30 & 37.5 & 50 \\
\hline 35 & 14.2 & -11.7 & 35 & 41.25 & 52.5 \\
\hline 40 & 18.3 & -8.3 & 40 & 45 & 55 \\
\hline 45 & 22.5 & -5.0 & 45 & 48.75 & 57.5 \\
\hline
\end{tabular}

Figure 8: Examples of dip limits separating unfavourable, neutral and favourable situations for (i) flat ground (slope $0^{\circ}$ ) and dip parallel to form lines, and (ii) a $30^{\circ}$ slope.

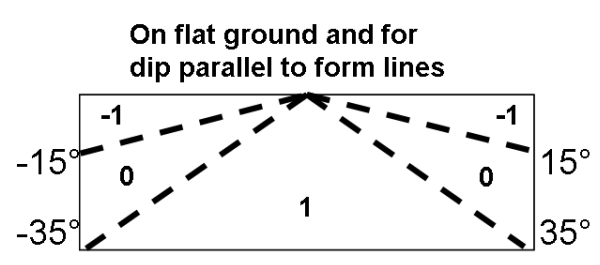

$-1=$ unfavorable; $0=$ neutral; $1=$ favorable

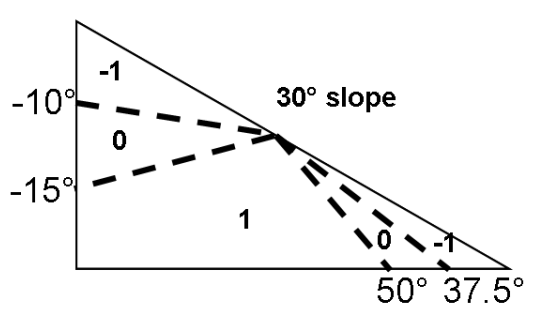




\section{A2.b. Textural Water Holding Capacity (WHC)}

Table 4: Water holding capacity $(\mathrm{mm} / \mathrm{m})$ of fine soil material for each texture class $s a=$ sand $; s i=$ silt $; c=$ clay. Capital letters indicate a dominant proportion, lower case a minoritory presence. In the last class (Sa.Si.C) the texture is balanced between the three materials. The CC class corresponds to heavy compact clays.

\begin{tabular}{cccccccccc} 
Sa & Sa.si & Sa.Si.c & Sa.Si & Sa.c & Sa.Si & Sa.C & Sa.si.C & Sa.Si.c & CC \\
\hline 70 & 100 & 117 & 122 & 135 & 145 & 152 & 157 & 160 & 165 \\
& & & & & & & & & \\
sa.C & Sa.Si.C & C & Si & sa.Si.C & C.si & S.Si.C & Si.C & Si.c & Sa.Si.C \\
\hline 170 & 170 & 175 & 175 & 176 & 180 & 181 & 187 & 195 & 200
\end{tabular}

Data adapted form GEPPA-SESCPF (1981)

\section{A2.c.Classes of solar energy budget.}

The energy budget is based on Becker index (Becker 1984). The Becker index corresponds to the ratio between the solar energy received on a plane area with a given orientation and slope and the same horizontal area. It is computed by equation 5 :

Equation 5 Becker index

$\operatorname{IKR}=(\operatorname{SIN}(\mathrm{H}-\mathrm{ATAN}(\mathrm{P} * \operatorname{COS}(\mathrm{E})))) / \operatorname{SIN}(\mathrm{H}) \quad$ with:

$\mathrm{H}=$ mean annual angle of the sun with the vertical at the studied site.

$\mathrm{P}=$ Slope of the site with the horizontal, in radians.

$\mathrm{E}=$ angle between the orientation of the site and the north, in radians.

The five classes used in this study (very hot, hot, neutral, cool and very cool) are shown in Figure 9.

IKR impact on Aleppo pine Site Index is climate dependent and inverse between cold-humid and hot-dry environments (see discussion end of section 4.1.2).

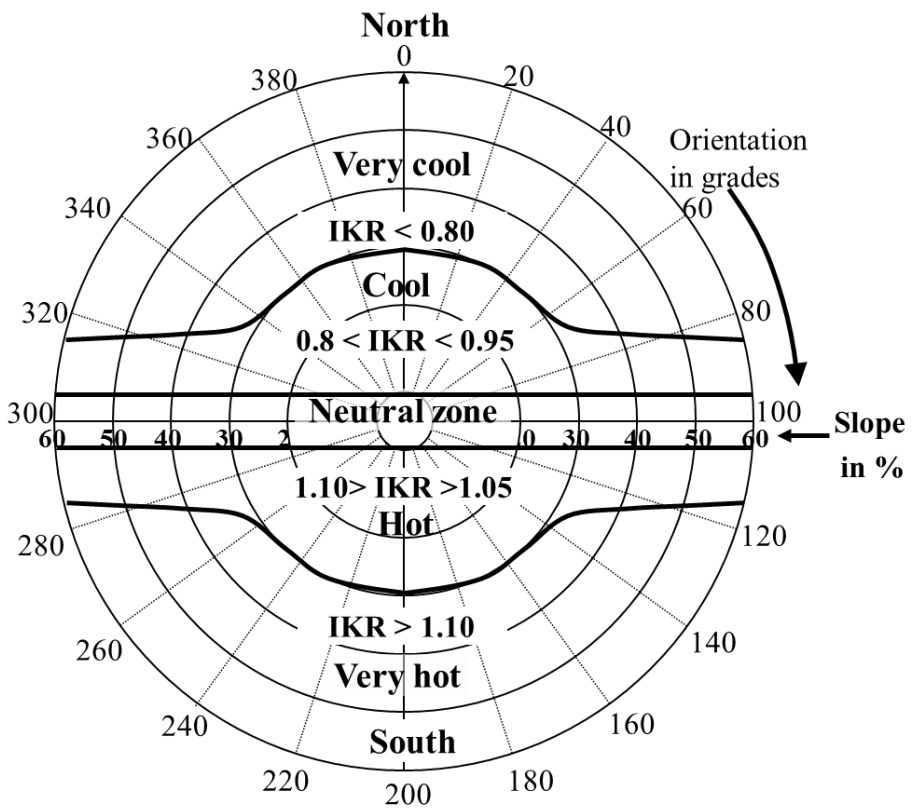

Fig. 9: Classes of Becker index (solar energy budget) according to slope angle (concentric circles) and orientation of the site. 
Vennetier, M.: Ripert, C., Rathgeber, C. - 2018. Autecology and growth of Aleppo pine (Pinus halepensis Mill.): a comprehensive study in France. Forest Ecology and Management. 413 (2018) 32-47. https://doi.org/10.1016/j.foreco.2018.01.028

Appendix C: Map of the study area with all 523 sample points (circles with a central dot). Many points are superposed at this scale, particularly in the middle of the study area where Aleppo pine stands are dominant but the overall density of point by sub-region is respected. (C) IGN Scan1000.

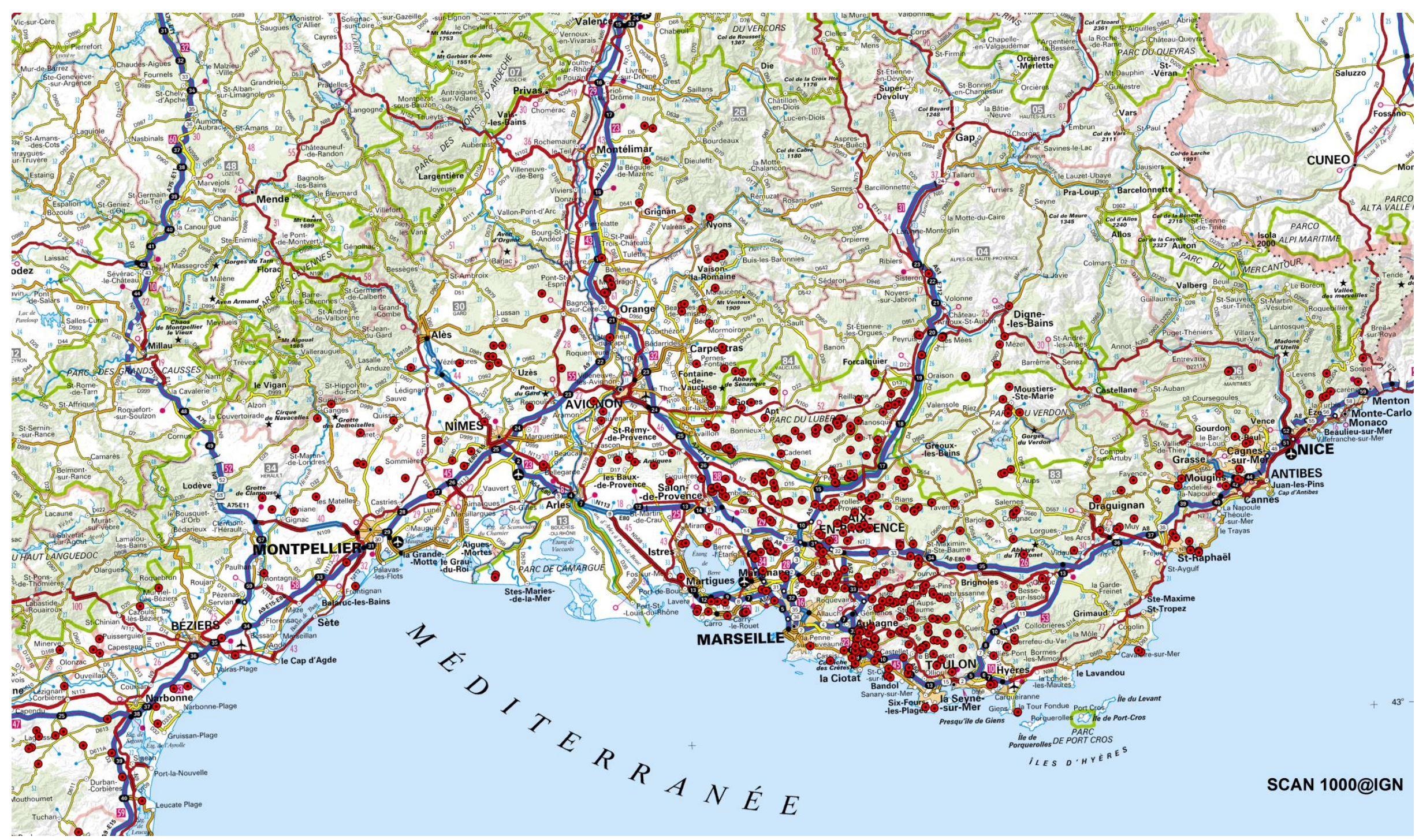


Vennetier, M.; Ripert, C., Rathgeber, C. - 2018. Autecology and growth of Aleppo pine (Pinus halepensis Mill.): a comprehensive study in France. Forest Ecology and Management. 413 (2018) 32-47. https://doi.org/10.1016/j.foreco.2018.01.028 